\title{
BACTÉRIAS ASSOCIADAS AO RAQUITISMO DAS SOQUEIRAS DA CANA-DE-AÇÚCAR (Saccharum sp.) E AVALIAÇÃO DO CAPIM ELEFANTE (D Dennisetum purpureum Schum.) COMO INDICADORA
}

\author{
SHINOBU SUDO
}

Engenheiró-Agrónomo

Orientador: Prof. Dr. Hasime Tokeshi

Dissertação apresentada à Escola Superior de Agricultura "Luiz de Queiroz", da Universidade de São Paulo, para obtenção do título de Mestre am Fitopatologia.

$P|R A C| C A B A$

Estado de São Paulo - Bresî Junho, 1980 
A memōria de meu pai, $\bar{a}$ minha mãe e meus irmãos, à minha esposa e filhos, 
0 autor expressa seus agradecimentos:

Ao Professor Dr. HASIME TOKESHI, pela valiosa orientação, de dicação e estímulo;

Aos Professores do Departamento de Fitopatologia, da Escola Superior de Agricultura "Luiz de Queiroz" da Universidade São Paulo, pelas importantes sugestões e estímulo;

A EMBRAPA, pelas facilidades concedidas durante o período da realização do Curso;

Aos Professores Charles Frederick Robbs e Osamu Kimura; da UFRRJ, pela colaboração na determinação de'bactērias e fornecimento de culturas bacterianas e material biblio gràfico;

Ao Engং-Agr? Alonso Keese Dodson, pela contribuição em est mulo e importantes sugestões;

Ao Eng:-Agr? Dr. Alvaro Sanguino, da COPERSUCAR, pela con tribuição em coleta de materiais e importantes sugestões;

Ao Professor M.S. Fujio Akiba, da UFRRJ, pelas sugestões e estímulo;

Ao Eng?-Agr? M.S. Yodiro Masuda, do IAA-PLANALSUCAR, pelas sugestões e estímulo; 
Ao Professor Dr. Raul de Lucena Duarte Ribeiro, da UFRRJ, p $\underline{e}$ las sugestões e revisão dos originais;

Ao Eng?-Agr? Dr. Sizuo. Matsuoka, do IAA-PLANALSUCAR, pelas importantes informações e material bibliográfico;

Ao Sr. José Ferreira da Costa, da EMBRAPA, pela colaboração na análise estatística dos experimentos;

A COPERSUCAR e IAA-PLANALSUCAR, pelas contribuições no for necimento de cultivares de cana-de-açūcar utilizadas e material bibliográfico;

Ao Instituto Zimotécnico da ESALQ e Departamento de Fitopatologia da FCMBB, pelo fornecimento de material utilizado;

Aos funcionārios do Departamento de Fitopatologia da ESALQ, pela colaboração nos trabalhos de laboratörio e campo;

Aos Funcionários da Secretaria do Curso de Pós-graduação da ESALQ, pela correspondéncia remetida e informações prestadas;

As Sras. Jacy da Silva, Euza da Rocha Masullo e Flora Maria de Souza Cardoso, pela colaboração prestada. 
Pág.

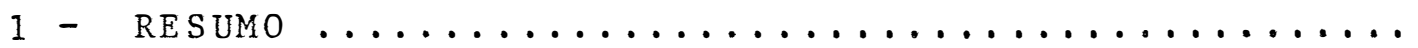

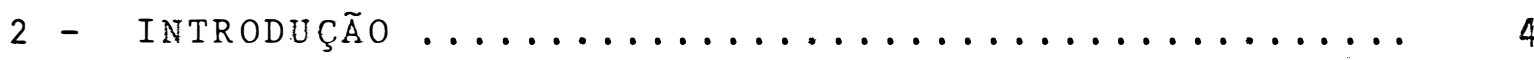

$3-\operatorname{Revisto~de~literatura~} \ldots \ldots \ldots \ldots \ldots \ldots \ldots \ldots$

3.1 - Agente causal do RSD ............. 8

3.2 - Sintomas para diagnose do RSD .......... 11

3.3 - Inativação térmica "in vivo" e "in vitro" do agente causal do RSD .............. 15

4 - MAteriats e MEtodos ........................... 20

4.1 - Isolamento de bactérias de colmos de cana-de-açücar com sintomas de RSD ......... 20

4.1 .1 - Características dos materiais e mé todos de isolamento ............. 20

4.1.2 - Identificação das bactérias isola das de colmos de cana-de-açūcar com

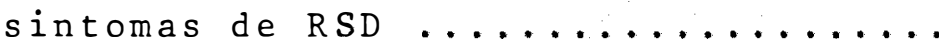

4.1.3 - Teste de patogenicidade das bactērias isoladas de colmos de cana-de açücar com sintomas de RSD ........ 23

4.1.4 - Avaliação das populações de Erwinia herbicola presentes no caldo obtido dos nós de colmos de cana-de-açūcar com sintomas de RSD ............ 26

4.1.5 - Isolamento de bactérias de colmos de cana-de-açūcar com sintomas de RSD, após o tratamento térmico dos

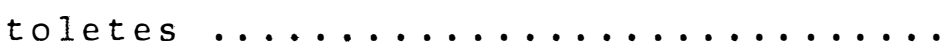


4.1 .6 - Ponto de inativação térmica "in vi tro" das bactérias isoladas de col mos de cana-de-açūcar com sintomas de $\operatorname{RSD} \ldots \ldots \ldots \ldots \ldots \ldots \ldots \ldots \ldots$

4.2 - Especificidade do teste de capim Elefante na diagnose do RSD da cana-de-açūcar ...

4.2.1 - Reação do capim Elefante à inocula ção com algumas bactérias fitopato

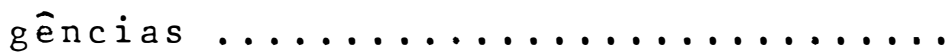

4.2.2 - Reação do capim Elefante à inocula ção com bactérias e fungos isola dos de cana-de-açūcar e leveduras encontradas em destilarias de aguar dente de cana-de-açūcar ...........

4.2.3 - Reação do capim Elefante à Fusarium moniliforme, Candida cruzei, Han senula anomala e Saccharomyces cerevisiae, inoculados, em diferen -

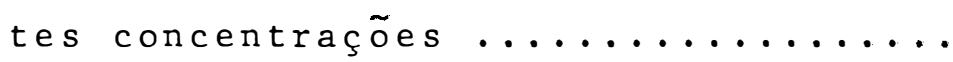

4.2.4 - Reação do capim Elefante à inocula ção com bactérias isoladas de colmos de cana-de-açūcar com sintomas de RSD, em diferentes concentrações.

4.2.5 - Reação do capim Elefante ao caldo extraído e às bactérias isoladas de colmos de cana-de-açūcar com sintomas de RSD, submetidas ou não à ina

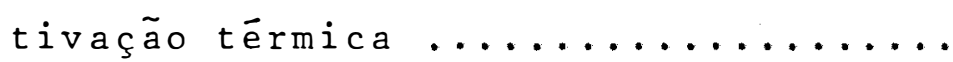


Pāg.

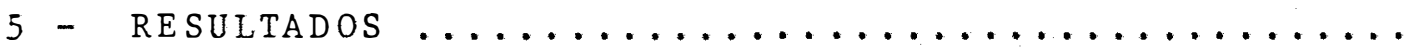

5.1 - Isolamento de bactérias dos colmos de ca na-de-açúcar com sintomas de RSD ...........

5.1.1 - Características das bactérias isoladas dos colmos de cana-de-açūcar com sintomas de RSD ..............

5.1.2 - Identificação das bactérias isoladas de colmos de cana-de-açūcar com sintomas de RSD ...............

5.1.3 - Teste de patogenicidade das bactérias isoladas de colmos de cana-de açúcar com sintomas de RSD ..........

5.1 .4 - Avaliação das populações de Erwi nia herbicola presentes no caldo ob tido dos nós de colmos de cana-deaçúcar com sintomas de RSD ......... 40

5.1 .5 - Isolamento de bactérias de colmos de cana-de-açúcar com sintomas de RSD, após o tratamento térmico dos

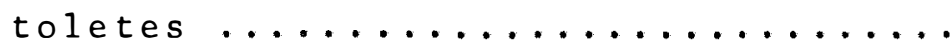

5.1 .6 - Ponto de inativação térmica "in ví tro" das bactérias isoladas de col mos de cana-de-açúcar com sintomas de $R S D \ldots \ldots \ldots \ldots \ldots \ldots \ldots \ldots$

5.2 - Especificidade do teste de capim Elefante na diagnose do RSD de cana-de-açúcar ...

5.2.1 - Reação do capim Elefante à inocula ção com algumas bactérias fitopato

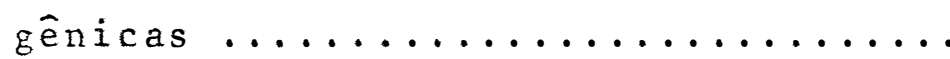


vii.

Pàg.

5.2.2 - Reação do capim Elefante à inocula ção combactérias e fungos isola dos de cana-de-açūcar e leveduras encontradas em destilarias de aguar

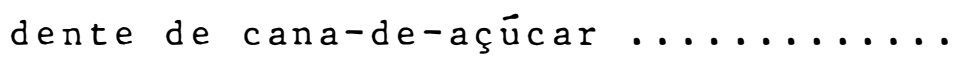

5.2.3 - Reação do capim Elefante à Fusarium moniziforme, Candida cruzei, Han senuza anomala e Saccharomyces cerevisiae inoculados, em diferentes

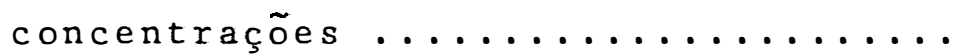

5.2 .4 - Reação do capim Elefante à inocula a ção com bactérias isoladas de colmos de cana-de-açūcar com sintomas de RSD em diferentes concentrações..

5.2 .5 - Reação do capim Elefante ao caldo e às bactérias isoladas de colmos de cana-de-açūcar com sintomas de RSD submetidos ou não à inativação

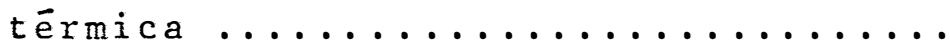

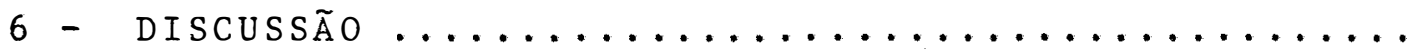

6.1 - Caracterização de bactérias associadas

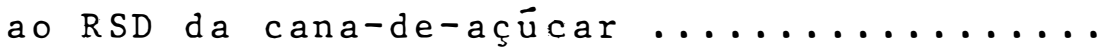

6.2 - Validade do teste com capim Elefante pa ra diagnose do RSD da cana-de-açūcar .....

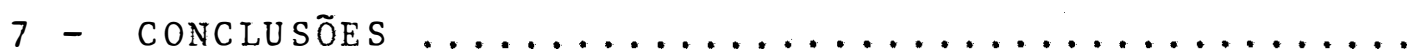

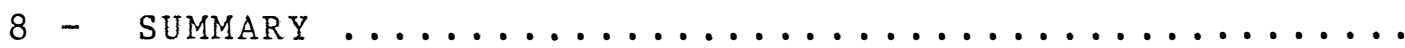




\section{LISTA DE TABELAS}

Pàg.

TABELA 1 - Tratamentos empregados no teste de patogenicidade de bactérias isoladas de col mos de cana-de-açūcar com sintomas de RSD .. 74

TABElA 2 - Bactérias fitopatogênicas usadas para tes tar a reação do capim Elefante ......... 75

TABELA 3 - Organismos usados para testar a reação do capim Elefante à inoculação com bactérias e fungos isolados da cana-de-açúcar, e leveduras encontradas em destilarias de aguardente de cana-de-açūcar .......... 76

TABELA 4 - Tratamentos empregados para testar a rea ção do capim Elefante à inoculação com diferentes concentrações de: Candida cru zei, F. moniziforme, Hansenula anomala e Saccharomyces cerevisiae .............

TABELA 5 - Tratamentos usados no teste de reação do capim Elefante à inoculação com diferentes concentrações de bactérias isoladas dos colmos de cana-de-açūcar com sinto-

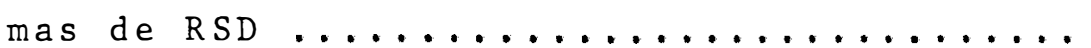

TABELA 6 - Tratamentos empregados para testar a rea ção do capim Elefante à inoculação com caldo extraído e com bactérias isoladas de colmos de cana-de-açūcar com sintomas de RSD, submetidos ou não à inativação térmica ....................... 
Pāg.

TABELA 7 - Teste de patogenicidade das bactérias iso ladas de colmos de cana-de-açúcar com sin tomas de RSD, em cana-de-açúcar, cultivar

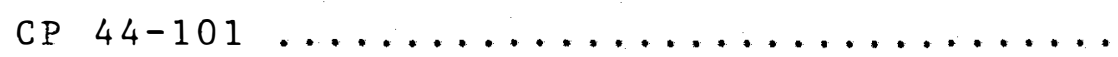

TABELA 8 - Populações de E. herbicola (C 1) em caldo obtido dos nós de colmos de cana-de-açū -

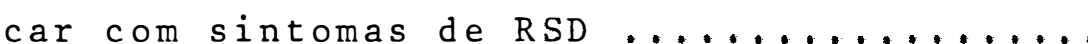

TABELA 9 - Ponto de inativação térmica "in vitro" das bactérias isoladas de colmos de cana-de-

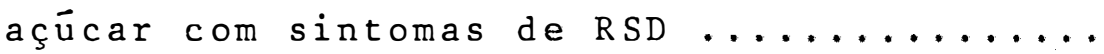

TABELA 10 - Descoloração vascular do capim Elefante após inoculação com algumas bactérias fi

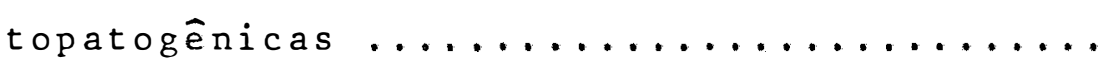

TABELA 11 - Descoloração vascular do capim Elefante após a inoculação com bactérias e fungos isolados de cana-de-açūcar e com leveduras mais comumente encontradas em destilarias e aguardente de cana-de-açūcar .....

TABELA 12 - Descoloração vascular do capim Elefante após inoculação com $F$. moniliforme e di versas leveduras, em diferentes concentrações $\ldots \ldots \ldots \ldots \ldots \ldots \ldots \ldots \ldots \ldots \ldots \ldots \ldots \ldots \ldots \ldots \ldots \ldots \ldots \ldots$

TABELA 13 - Descoloração vascular do capim Elefante após inoculação com diferentes concen trações de bactérias isoladas de colmos de cana-de-açūcar com sintomas de RSD .... 
TABELA 14 - Descoloração vascular do capim Elefante após a inoculação com caldo extraído e com bactérias isoladas de colmos de cana-de-açūcar com sintomas de RSD, submetidas ou não à tratamento térmico ....... 86 
1 - RESUMO

Estudos realizados a partir de material de cana-deaçūcar com sintomas de raquitismo das soqueiras ("Ratoon Stun ting Disease") revelaram a presença de bactérias identificadoras como Erwinia herbicola e Pseudomonas rubrisubalbicans. E. herbicola foi constatada em todas as cultivares trabalhadas: IAC 52/326, Q 28, CP 44-101, CB 41-76, CB 49-260 e IAC $48 / 65$, ao passo que $P$. rubrisubalbicans só foi detectada nas cultivares IAC 52/326, Q 28 e CP 44-101. A patogenicidade dessas bactērias foi aferida, inoculando-se plantas de cana-de-açūcar, cultivar CP 44-101, que mostraram sintomas in ternos de descoloração vascular associados ao raquitismo das soqueiras.

Avaliações das populações de E. herbicola presentes no caldo extraído da região nodal de colmos de cana-de-açūcar com sintomas da doença revelaram niveis da ordem de 1,2 a $2,8 \cdot 10^{8}$ e 0,7 a $3,8 \cdot 10^{6}$ células viàveis por mililitro pá 
ra as cultivares IAC $48 / 65$ e IAC 52/326, respectivamente.

Os resultados do estudo sugeriram que $E$. herbicola deve estar envolvida na etiologia do raquitismo das soqueiras e que $P$. rubrisubalbicans merece ser melhor investigada sob es se àngulo. E. herbicola revelou estar constantemente asso ciada com material doente, reproduziu parte dos sintomas quan do inoculada em cana-de-açūcar e atingiu populações relativamente altas em tecidos do colmo.

Isolamentos efetuados apōs o tratamento térmico de toletes originadoð̧s de colmos de cana-de-açūcar com sintomas de RSD, a $50,5^{\circ} \mathrm{C}$ por duas horas, indicaram que esse tratamento foi capaz de proporcionar inativação total de P. rubrisu balbicans, porēm, inativação apenas parcial no que tange a E. herbicola.

Tratamento térmico em àgua quente de $E$. herbicola e P. rubrisubalbicans, "in vitro", revelou que P. rubrisubalbi cans è completamente inativada quando submetida à temperatura de $50^{\circ} \mathrm{C}$ por 20 minutos, enquanto que, para $E$. herbicola e para igual período de imersão, temperaturas de até $52^{\circ} \mathrm{C}$ não foram suficientes para inativação total. Para essa ūitima espê cie, inativação total somente foi obtida à temperatura de $54^{\circ} \mathrm{C}$.

Para aquilatar a validade do teste de capim Elefante (MATSUOKA, 1972a) na diagnose do RSD, foram conduzidos vārios ensaios, inoculando-se plantas da cultivar Merker dessa gramínea com diversas espécies de bactérias, fungos e leveduras. O capim Elefante reagiu positivamente, através do apare 
cimento de descoloração vascular, quando inoculado com Erwinia herbicola, E. carotovora, Pseudomonas rubrisubalbicans, P. rubrilineans, P. mori, Xanthomonas albilinenas, Fusarium moniliforme, Candida cruzei, Hansenula anomala e Saccharomy ces cerevisiae. Os sintomas internos observados pareceram dēnticos àqueles induzidos na planta-teste quando inoculada com caldo bruto extraído de colmos de cana-de-açūcar com raquitismo das soqueiras. Foi observado também que a intensida de da reação do capim Elefante depende do microorganismo inoculado e do número de propágulos presentes no inōculo. A con centração mais baixa capaz de induzir resposta positiva foi de, aproximadamente, $10^{1}$ propágulos por mililitro de suspen são, conseguida com F. moniliforme. Esses dados somaram evi déncias de que o capim Elefante reage inespecificamente, por descoloração, dos vasos da região dos nós, não sendo, portanto recomendado como indicadora para diagnóstico do raquitismo das soqueiras. 
A cultura da cana-de-açūcar (Saccharum sp.) é uma das explorações agrīcolas de mais ampla distribuição geográfica, revestindo-se de grande importāncia econōmica e social. As inūmeras empresas e instituições que subsistem em função da cana-de-açūcar na produção e transformação do açūcar, ge ram atravēs dessa atividade riquezas de considerāvel expressão, tanto em divisas, como em empregos, beneficiando, assim, todos os países onde é cultivada em grande escala.

o Brasil, como maior produtor mundial de açūcar de cana e em decorréncia da escassez e carestia do petróleo, par te agora para a produção em escala comercial de álcool com bustivel, programa este que, certamente, contribuirá para grande economia de divisas, reduzindo as importações de petróleo. Dentro da execução dessa programação, vārios projetos ja estão em andamento e muitos outros em fase de planeja mento, visando à expansão da cultura, bem como a implantação 
de novas usinas e destilarias de ālcool.

Contudo, a produtividade da cana-de-açúcar no Brasil está ainda muito aquém daquelas conseguidas no Hawai, na Africa do Sul ou na Austrālia. Sem dūvida alguma, um dos fá tores que m ais concorrem para nossa baixa produtividade é re presentado pelo conjunto de doenças e pragas que incidem sobre os canaviais.

Das inūmeras doenças que afetam a cana-de-açūcar,o raquitismo das soqueiras (RSD), representa uma das mais importantes. Segundo GALLI et alii (1968) essa enfermidade po de causar um a queda de producão da ordem de 20 a $60 \%$.

o raquitismo das soqueiras foi constatado inicialmente na Austrāilia por volta de $1944-1945$ (STEINDL e RUGHES, 1953), causando quebras na tonelagem de soqueiras da culti var Q 28. Atualmente, a doença está disseminada por todas as regiões do Globo que se dedicam à cultura de cana-de-açūcar. No Brasil, os primeiros relatos de raquitismo das soqueiras foram os de VEIGA (1956) e DANTAS (1956).

Durante muitos anos o agente incitante da doença foi considerado como de natureza viral. No entanto, a partir de 1970 , muitos pesquisadores passaram a manifestar dúvidas a esse respeito. Dentre eles, STEIB e TANTERA (1970), referiram-se à possibilidade da associação de um micoplasma com a moléstia. PLAUSIC-BANJAC e MARAMOROSHI (1972), GIL LASPIE JR. et alzi (1973) e TEAKLE et alii (1974) encontra ram constante associação de bactērias com plantas apresentan 
do sintomas da doença. De canas com raquitismo, LIU et alii (1974) isolaram uma bactéria similar a Xanthomonas vasculorum e TOKESHI et alii (1974), uma outra bactéria com característí cas idēnticas a $X$. albizineans. Vários outros autores como CHEM et alii (1975), GILLASPIE JR. et alii (1976), DAMANN e DERRICK (1976), RICAUD et alii (1976) e MAMIUNTEN e WAKIMOTO (1976), relataram uma constante associação de bactérias corineformes com plantas afetadas pela doença. Assim, atualmente desenvolveu-se um consenso geral de que o RSD é uma doença de etiologia bacteriana. Todavia, existem ainda dúvidas quanto à identidade da bactéria ou bactérias que causam a enfermidade.

Por outro lado, a difícil diagnose da doença condu ziu vārios pesquisadores a investigar métodos mais práticos, rápidos e eficientes para detectar plantas afetadas. Alguns deles como STEINDL e HUGHES (1953), SCHEXNAYDER (1960), GIL LASPIE JR. et alii (1966) e RICAUD (1974) recorreram a inoculações em cultivares de cana-de-açūcar suscetíveis que mostras sem sintomas precoces de raquitismo. Outros, como GILLASPIE JR. et alii (1973) , STEINDL e TEAKLE (1974) e STEINDL (1976), recorreram ao exame de material suspeito no microscópio ele trōnico ou de contraste de fase. MATSUOKR (1972a) desenvol veu um método de diagnose rápido do raquitismo utilizando o capim Elefante (Pennisetum purpureum Schum. CV. Merker) como planta indicadora. No entanto, BETTI et alii (1976) contestaram os resultados de MATSUOKA (1972a), mencionando que vā- 
rias espécies bacterianas eram capazes de provocar sintomas se melhantes em capim Elefante quando veiculadas através do suco extraîdo de touceiras de cana doentes.

0 presente trabalho teve como objetivos principais: 1) contribuir para a identificação de bactérias associadas aos sintomas de raquitismo das soqueiras; e 2) determinar a reação e a sensibilidade do capim Elefante em relação à inocú lação com diversos microorganismos, devidamente identificados, passiveis de mascarar a diagnose da doença pelo método preconizado por MATSUOKA (1972a).

Nesta pesquisa, o raquitismo das soqueiras é sem pre referido como RSD, sigla esta derivada de "Ratoon Stun ting Disease", designação aceita e empregada internacional . mente no trato científico com a enfermidade.

0 mesmo foi desenvolvido no Departamento de Fitopa tologia da Escola Superior de Agricultura "Luiz de Queiroz", da Universidade de São Paulo, Piracicaba, SP. 
8.

3 - REVISAO DE LITERATURA

3.1 - Agente Causal do RSD

Segundo STEINDL e HUGHES (1953) o RSD ("Ratoon Stunting Disease"), foi observado pela primeira vez em Queesland, na Austrália, no distrito de Makay, por volta dos anoś 1944 - 1945. A doença incidia sobre a cultivar Q 28 e os sintomas apresentados eram traduzidos por um crescimento subnormal e irregular da soqueira. No Brasil, as primeiras constatações são de VEIGA (1956), em Campos, no Estado do Rio de Ja neiro e de DANTAS (1956) em Pernambuco. Atualmente a enfermi dade está disseminada por todos os Estados do Brasil e por to dos os paises canavieiros do mundo (GALLI et alii, 1968).

Conforme relatam STEINDL (1961), CARVALHO. (1963), e GALLI et alii (1968), a rāpida propagação da doença por todas as regiões de cana-de-açūcar do mundo, deve-se, principa 
mente, às constantes trocas de material vegetativo entre os principais paises produtores.

Pela dificuldade de se visualizar quaisquer microor ganismos associados aos sintomas e pela sua fácil transmissibilidade para plantas sadias, durante longo tempo, muitos autores como STEINDL e HUGHES (1953), HUGHES e STEINDL (1955), SCHEXNAYDER (1956), FORBES et azii (1960), LING (1960), TODD (1960), STEINDL (1961), ADSUAR e ROSA (1962), CARVA LHO (1963) , GILLASPIE et alii (1966), EL-BANNA e MOURSI (1967), GALLI et alii (1968), GILLASPIE (1970a e 1970b, 1971) e ZUMMO (1974), consideraram o agente causal do RSD como sendo, possivelmente, um virus. STEIB e TANTERA (1970), fo ram os primeiros a estabelecer dúvidas quanto à etiologia viral da doença referindo-se à possível associação de um micoplasma com os sintomas de RSD.

Vários trabalhos sucederam-se, como os de PLAUSIC BANJAC e MARAMOROSCH (1972), GILLASPIE JR. et alii (1973), TEAKLE et alii (1974), TEAKLE (1974), GILLASPIE JR. (1974) e GILLASPIE JR. et alii (1974), mostrando existir constante as sociação de bactérias com plantas apresentando sintomas de RSD. Em Porto Rico, LIU et alii (1974) isolaram uma bactéria de plantas com sintomas de RSD, considerada similar a Xanthomonas vasculorum. TOKESHI et alii (1974), por seu turno, isolaram uma bactéria com características semelhantes a $X$. albizineans e a responsabilizaram como possivel agente causal do RSD, mos trando, ainda, que a diferença entre as estirpes dessa espé - 
cie associadas com a escaldadura e com o RSD, residia apenas nas temperaturas requeridas para inativação. Trabalhos mais re centes de CHEN et alii (1975), GILLASPIE JR. et alii (1976). DAMMAN e DERRICK (1976), RICAUD et a $i$ i (1976) e MAMIUNTEN e WAKIMOTO (1976), confirmam que uma bactéria corineforme encontra-se associada a plantas com RSD.

GILLASPIE JR. et alii (1976), estudando comparativa mente as bactérias associadas ao RSD por diferentes pesquisadores, com aquelas achadas por eles na Louisitana, chegaram à conclusão de que há certa discrepāncia com respeito ãs dimensões desses organismos. Enquanto outros autores, citam valores variando entre $0,12-0,5 \times 0,6-3,0$ micrōmetros, as células detectadas por GILLASPIE JR. et alii (1976) estão na faixa de $0,3-0,5 \times 5,0-10,0$ micrōmetros.

BAILEY (1977), examinando plantas de trés cultiva res de cana-de-açūcar com RSD, verificou que a bactéria está presente em todas as partes da planta, sendo que nas regiões basais as populações eram sempre mais elevadas que nas partes superiores dos colmos. BAILEY (1977) notou ainda que essas po pulações variavam de acordo com a maior ou menor suscetibilidade da cultivar.

Apesar desses autores referirem-se ao envolvimento de bactérias com O RSD, a maioria deles não comprovou a patogenicidade dos microorganismos associados ã doença. Apenas TOKESHI et alii (1974) o fizeram, utilizando-se, para tal, de plantas indicadoras e de cultivares de cana-de-açúcar recomen dadas para diagnóstico do RSD. 
3. - Sintomas para Diagnose do RSD

O RSD foi considerado, durante algum tempo, como do crça sem sintomas característicos ou especificos que pudessem A.singuíl-10 de outras doenças que induzissem colmos atrofiados, subdesenvolvmento e variações na altura e no rendimento dos plantas no campo. HUGHES e STEINDL (1955) descreveram,pe 7a primeira vez, sintomas internos do RSD que, em determina tas cultivares, manifestam-se na forma de pontuações, vírgu las ou bastonetes rosados, amarelados ou avermelhados, nos fe $i$ xes vasculares da região nodal de colmos maduros e que, em nōs imaturos próximos ao meristema apical, apresentam coloração ligeiramente rósea, observados logo após efetuar-se o corte dos colmos doentes.

SCHEXNAYDER (19.60), STEINDL (1961) , GILLASPIE JR. et alii (1966), CARVALHO (1963), GALII et alii (1968) e MAT SUOKA (1971 e 1972a) referem-se, também, aos sintomas acima descritos, em associação ao RSD.

HUGHES e STEINDL (1955) e GILLASPIE JR. et a $i i$

(1966) salientam que os sintomas internos de modificação de cor dos vasos, devem ser encontrados em vārios nós dos colmos para diagnose segura do RSD e que pontuações castanho-avermelhadas, mais escuras, devem ser disconsideradas, uma vez que mesmo plantas sadias podem possuí-las. Mencionam ainda o fato de que os sintomas de RSD variam com a idade do colmo e com as condições climáticas das regiões de cultivo. STEINDL (1961) e ROSSLER (1974), submetendo cultivares de cana com RSD 
a diferentes nīveis de irrigação, confirmaram a existēncia de fatores que influenciam e dificultam o diagnóstico através de sintomas internos.

RICAUD (1974), referindo-se à diagnose do RSD, indi ca que muitos são os fatores que podem influenciar a manifestação dos sintomas e que, em determinadas condições, os sintó mas internos não permitem uma interpretação acurada de suas causas. Devido às dificuldades para diagnose do RSD, sugere RICAUD (1974) que esforços devam concentrar-se no isolamento de seu agente causal e no desenvolvimento de métodos mais específicos para essa diagnose, objetivando confirmar a ocorrēn cia da doença em diferentes regiões geogräficas.

Para GILLASPIE JR. et alii (1973), o RSD da cana-de - açūcar pode ser diagnosticado pelo exame do exsudato do xile ma ou do caldo extraído de canas doentes, empregando microscō pios de contraste de fase ou de campo escuro, pela visualização da pequena e delgada bactēria associada à doença.

STEINDL e TEAKLE (1974), propõem a identificação do RSD atravēs de quatro métodos: 1) existēncia de sintomas in ternos em plantas afetadas;2) reprodução do sintomas pela inoculação do caldo extraído de colmos doentes na cultivar Q 28 ; 3) manifestação de sintomas em plantas indicadoras co mo capim Elefante, clone Bana; e 4) detecção de uma pequena bactéria no extrato da seiva da região fibro-vascular de canas afetadas, usando o microscópio eletrónico 
STEINDL (1976) relatando um novo método para indentificação de RSD, afirma que na seiva retirada à vācuo dos vasos e posteriormente concentrada por meio de centrifugação, é possível observar grande quantidade de diminutas e cilindri cas células bacterianas ao microscōpio de fase, que evidenciam tratar-se do RSD. Friza, também, que esse método de diagnose é muito mais rápido e satisfatōrio do que aquele baseado no teste em capim Elefante ou na observação ao microscópio ele trōnico. STEINDL (1976) recomenda o método para confirmação da diagnose, quando os exames rotineiros deixam dúvidas. No entanto, enfatiza que nenhum método é mais eficiente do que a inoculação do caldo na cultivar $Q 28$ de cana-de-açūcar.

Em decorrēncia dos problemas ligados à diagnose do RSD pela simples interpretação aos sintomas, vārios pesquisadores têm recorrido a métodos de diagnose envolvendo a inoculação de plantas-teste. Assim, STEINDL e HUGHES (1953) utili zaram a cultivar Q 28 como indicadora ; SCHEXMAYDER (1960), testou sete cultivares de cana, sendo que a CP 36-105 foi a que melhor se comportou, com $100 \%$ das plantas inoculadas apre sentando reação positiva. Segundo GILLASPIE JR. et alii (1966), sintomas precoces de RSD foram exibidos mais nitidamente pela cultivar CP 44-101. MATSUOKA (1971 e 1972a) preconiza o uso do capim Elefante no diagnóstico do RSD, inoculando-se o cal do extraido de canas doentes ou suspeitas por meio de corte de palmito foliar. No caso de caldo proveniente de canas com RSD, as plantas-teste reagem mostrando descoloração dos vasos 
da região basal do palmito inoculado, em apenas trēs semanas. RICAUD (1974), relata que a diagnose do RSD pode ser feita através da inoculação de cultivares indicadoras de cana, tais como: Q 28, CP 36-105, CP 44-101 e Co 421. Salienta, no entanto, que essas cultivares apresentam o inconveniente de não mostrarem sintomas nos casos em que a concentração do inō culo é baixa. TOKESHI et alii (1974) comprovaram a patogenicidade de $X$. albilineans, estirpe X RSD, citada como agente incitante do RSD, através de sintomas positivos obtidos após inoculações em milho doce, capim Elefante e nas cultivares de cana-de-açūcar CP 44-101, CB 45-155, Trojan, H507209 e CB 44-77. IRWINE (1976), recomenda a cultivar CP 44-101 para diagnose do RSD, observando que plantas adubadas semanalmente com nitrato de amōnio ou fórmula NPK completa, respondem com sintomas mais acentuados e que, nessas condições, os sintomas expressaram-se em 100\% dos indivíduos, com 43 dias de inoculados. BECHET (1976), cita que certos clones de Bana grass (hibrido de Pennisetum purpureum $\times P$. americanum) mostraram-se promissores como hospedeiros indicadores para rápido diagnóstico do RSD e que o tempo necessário para leitura dos sintomas foi de apenas trēs semanas. Esses resultados, en tretanto, pouco diferem daqueles obtidos por MATSUOKA (1972.a e 1972.b) com capim Elefante cultivar Merker.

As primeiras tentativas de diagnose do RSD através do uso de métodos serológicos foram as de STEINDL e HUGHES (1953) que, contudo, não chegaram a resultados satisfatórios. 
STEINDL (1961) afirma que até aquela data, todas as tentati vas para obtenção de antissoro contra o agente do RSD haviam falhado. Mais recentemente, GILLASPIE JR. et alii (1976) e GILLASPIE JR. (1977), sugerem que o método sorolōgico poderia ser utilizado na diagnose do RSD, mas que, no entanto, isso somente seria possivel tratando-se de cultivares que apresentassem alta concentração de bactérias. Assim sendo, concluem esses ūitimos autores que a serodiagnose ainda não é um método adequado para o caso de cultivares de cana-de-açūcar menos suscetíveis ao agente do RSD. VALARINI (1978), estudando o fluxo de água em colmos de cana-de-açūcar, observou a existēn cia de grandes diferenças entre plantas atacadas de RSD e plan tas sadias, principalmente nas cultivares mais suscetiveis. Já nas cultivares tolerantes, essas diferenças foram bem pequenas. As plantas atacadas apresentaram fluxo sempre menor do que as sadias. O autor salierta que, por esse método, não só é possível diagnosticar plantas afetadas com RSD como também aquilatar o grau de suscetibilidade de uma determinada cul tivar.

3.3 - Inativação térmica "in vivo" e "in vitro" do agente causal do RSD

0 método mais comumente empregado para o controle do RSD tem por base o tratamento térmico dos colmos das canas-plan ta visando à obtenção de material propagativo sadio para os 
campos de multiplicação.

STEINDL e HUGHES (1953), recomendam o uso de āgua quente no tratamento dos colmos, para eliminar o agente causal do RSD. Frizam todavia que a temperatura da āgua e o tem po de imersão dos toletes são fatores críticos que devem ser cuidadosamente observados. Assim, à temperatura de $50^{\circ} \mathrm{C}, 0$ tempo de imersão deverá ser de 90 minutos; à $52^{\circ} \mathrm{C}$, de 60 a 90 minutos; a $54{ }^{\circ} \mathrm{C}$, de 45 a 75 minutos; à $55^{\circ} \mathrm{C}$, de $60 \mathrm{mi}-$ tos e a $58^{\circ} \mathrm{C}$, de 30 minutos. Mencionam, também, que trata a $50^{\circ} \mathrm{C}$ por 24 horas ou a $54^{\circ} \mathrm{C}$ por oito horas, utilizan quente, podem, da mesma forma, erradicar o agente do RSD na cultivar Q 28. Em pesquisa subsequente, HUGHES e STEINDL $(1955)$, recomendam o emprego de ar quente a $53-54{ }^{\circ} \mathrm{C}$ por oito horas ou a $50^{\circ} \mathrm{C}$ por 24 horas, em conformidade com os resultados do trabalho anterior; porém, no que tange ao tratamento com gua quente a $50^{\circ} \mathrm{C}$, afirmam que o tempo de imersão deveer aumentado para 120 minutos.

SCHEXNAYDER (1956), relata que a cura de plantas in fectadas pelo agente do RSD pode ser conseguida através da aplicação de ar quente a $54^{\circ} \mathrm{C}$ por oito horas e que, apesar des se tratamento não erradicar totalmente o agente infeccioso, proporciona grande aumento na produtividade. O próprio SCHEX NAYDER (1960), em trabalho de seleção de plantas-teste para diagnóstico do RSD, obteve controle total da doença, tratando os toletes, antes da extração do caldo para inoculação, em àgua quente a $50^{\circ} \mathrm{C}$ por duas horas e meia. 
FORBES et azii (1960), recomendam o tratamento dos toletes com ar quente a 58 ou $59^{\circ} \mathrm{C}$, dependendo da cultivar, por oito horas, para se obter controle satisfatōrio do RSD. TODD (1960), cita que, na Flörida, o tratamento comágua quente a $51^{\circ} \mathrm{C}$ por duas horas ou a $50^{\circ} \mathrm{C}$ por duas horas e meia é re comendado para máximo controle da enfermidade. CHENULU (1960) conseguiu a cura de toletes doentes pelo tratamento com água quente a $50^{\circ} \mathrm{C}$ por 90 minutos; $52^{\circ} \mathrm{C}$ por 60 minutos; $54^{\circ} \mathrm{C}$ por 45 minutos e $58^{\circ} \mathrm{C}$ por 30 minutos. Outra alternativa que CHENULU (1960) recomenda o uso de ar quente a $50^{\circ} \mathrm{C}$ por 24 horas ou a $54^{\circ} \mathrm{C}$ por 8 horas. 0 s dados referentes aos tratamentos são idēnticos aos indicados por STEINDL e HUGHES (1953) e HUGHES e STEINDL (1955), com a diferença de que às temperaturas de $52{ }^{\circ} \mathrm{C}$ e $54^{\circ} \mathrm{C}$, CHENULU (1960) recomenda os tempos de imer são mỉnimos, de 60 e 45 minutos ao inves de 60 a 90 e 45 a 75 minutos, respectivamente. BOURNE (1962), preconiza o tratamento em água quente a $50^{\circ} \mathrm{C}$ por 24 horas para se obter $100 \%$ de eficiéncia no controle ao RSD.

CARVALHO (1963) concluiu que o tratamento com āgua quente a $50-52^{\circ} \mathrm{C}$ por 3 a 4 horas, é o mais eficaz e o mais empregado, ressalvando que temperaturas abaixo de $50^{\circ} \mathrm{C}$ não inativam o virus e que, acima desse nível, as gemas dos tole tes são destruídas. EL-BANNA e MOURS (1967) obtiveram resul tados satisfatōrios com o uso de água quente a $52^{\circ} \mathrm{C}$ por $90 \mathrm{mi}$ nutos, $54^{\circ} \mathrm{C}$ por 75 minutos e $56^{\circ} \mathrm{C}$ por 60 minutos. Salientam que o tratamento a $50^{\circ} \mathrm{C}$ por 120 minutos não foi suficiente pa 
ra completa inativação do virus. Já através da aplicação de ar querite, os melhores tratamentos foram obtidos com $50^{\circ} \mathrm{C}$ por 6 horas e $56^{\circ} \mathrm{C}$ por 1 hora e meia a 2 horas. GALLI et alii (1968), recomendam o tratamento térmico dos toletes, imergindo-os em àgua quente a $50,5{ }^{\circ} \mathrm{C}$ por 2 horas. LOPES-ROSA e AD SUAR (1970) demonstraram que o tratamento de canas infectadas com o virus do RSD em água quente a $50^{\circ} \mathrm{C}$ por 3 horas, não erradica o agente da doença, mas proporciona controle muito bom, verificando-se diferenças na produção da ordem de $20 \%$ entre ca nas tratadas e não tratadas. STEIB e CHILTON (1972) enfati zam, também, a importāncia do controle do RSD e efetuando o tratamento dos toletes com ar quente obtiveram aumentos de pro dução da ordem de 12,1 a $32,8 \%$ no primeiro corte e de 28,7 a $45,8 \%$ no segundo corte, com as cultivares CP 61-37, L 60-25 - e L 62-96. SILVA (1976), trabalhando com gemas individuais e tratando-as a $50,5^{\circ} \mathrm{C}$ por 2 horas, pōde controlar totalmente 0 RSD na formação de canas-planta. STEIB et alii (1976), obtiveram ótimos resultados atravēs do uso de vapor quente a $51^{\circ} \mathrm{C}$ por 4 horas. Com esse novo método, conseguiram controle completo do RSD, mantendo uma germinação de $90 \%$ em trés cultiva res testadas.

Analisando conjuntamente os dados constantes da literatura revista, observa-se que todos os tratamentos envol vendo temperaturas acima de $51{ }^{\circ} \mathrm{C}$ conduziram a resultados satisfatōrios no controle do RSD. Quando, em contra-partida,as temperaturas do tratamento situaram-se na faixa de 50 a $51^{\circ} \mathrm{C}$, 
alguns autores obtiveram resultados satisfatórios, enquantos outros não os conseguiram.

Com relação à inativação térmica "in vitro" do agente do RSD, poucos são os trabalhos até hoje registrados. FAR RAR (1957), verificou que o agente do RSD era inativo quando aquecido o caldo a $52^{\circ} \mathrm{C}$ por 15 minutos ou a $55^{\circ} \mathrm{C}$ por $10 \mathrm{minu}-$ tos. MATSUOKA (1972a), utilizando o teste em capim Elefante, observou que o agente do RSD era totalmente inativado quando o caldo bruto de canas doentes era aquecido a $55-60^{\circ} \mathrm{C}$ por 10 minutos. TOKESHI et alii (1974) mostraram que a bactéria por eles isolada de material com RSD ( $X$. albizineans $X$ RSD) resis tiu a temperaturas de até $54{ }^{\circ} \mathrm{C}$ durante 15 minutos.

Com respeito às exposições a temperaturas baixas, HU GHES (1957) constatou sobrevivência do agente do RSD, "in vivo", por mais de 138 dias à temperatura de $-20^{\circ} \mathrm{C}$. MATSUOKA (1972a) demonstrou a manutenção da viabilidade do agente do RSD por mais de 81 dias, "in vitro", e por mais de 125 dias, "in vivo", à temperatura de $-15^{\circ} \mathrm{C}$. TOKESHI et alii (1974), verificaram que $X$. albizineans $\times 419$, (isolada de canas com escaldadura), resistiu à temperatura de $-15^{\circ} \mathrm{C}$ por mais de 182 dias, "in vitro", e por mais de 355 dias, "in vivo". Assim, essas investigações mostraram perfeitamente que, a tempe raturas de congelamento (até $-20^{\circ} \mathrm{C}$ ), o agente do RSD permane ce viāvel por um período consideravelmente longo. 
4 - MATERIAIS E METODOS

4.1 - Isolamento de Bactērias de Colmos de Cana-de-Açúcar com Sintomas de RSD

4.1.1 - Características dos materiais e métodos de isolamento

Para os isolamentos de bactérias de cana-de-açūcar com sintomas de RSD, foram usados colmos de trés cultivares al tamente suscetiveis: IAC 52/326, Q 28 e CP 44-101 e duas me nos suscetíveis: CB 41-76 e CB 49-260 (VALARINI, 1978 e GALLI et alii, 1980).

Canas das cultivares IAC $52 / 326,028$, CB 41-76 e CB 49-260 com RSD, foram provenientes da Estação Experimen tal de Araras, Estado de São Paulo, pertencente ao IAA-PLANAL SUCAR ; canas da cultivar CP 44-101 foram obtidas na Estação Experimental da COPERSUCAR em Piracicaba, Estado de São Paulo. 
As canas das cultivares IAC $52 / 326$ e Q 28 foram coIhidas de touceiras de cana-soca, originadas de toletes trata tados termicamente, antes do plantio, pelo método convencio nal $\left(50,5^{\circ} \mathrm{C}\right.$ durante 2 horas) recomendado para eliminar o agen te causal do RSD (GALLI et alii, 1968).. Apesar das plantas nao apresentarem nenhum sintoma externo, grande nūmero de vasos na região dos nōs apresentavam-se descoloridos. As canas das cultivares CB 41-76 e CB 49-260 eram do primeiro corte e, da mesma forma, oriundas de toletes submetidos a tratamento térmico; essas canas não apresentavam sintomas externos e mos travam, apenas uma leve descoloração vascular nas regiōes nodais.

Canas da cultivar CP 44-101 eram também de primeiro corte, sendo, no entanto, derivadas de toletes que não recebe ram o tratamento térmico convencional; seu desenvolvimento $\underline{e}$ ra aparentemente normal, mas apresentavam sintomas severos de vasos descoloridos. De cada cultivar, foram escolhidos cinco colmos provenientes de touceiras diferentes sem broca ou rachadura e revelando nītida descoloração vascular. Dessa maneira, o critério fundamental empregado para diagnóstico do RSD residiu na constatação da presença de vasos descoloridos na região dos nōs.

Na cultivar IAC $52 / 326$ os colmos foram cortados, aproveitando-se, apenas, a parte basal, portando de 5 a 7 gemas. No laboratório, esses toletes foram raspados com canive te, mergulhados em àlcool, flambados em fogo direto e descas- 
cados assepticamente. Os vasos descoloridos foram localiza dos por meio de cortes longitudinais paralelos, eliminando-se, gradativamente, finas camadas de tecidos das regiões nodais, até atingir os feixes vasculares profundos. Estes foram reti rados cuidadosamente com a ponta do canivete, selecionando-se dez seguimentos por colmo. Os segmentos extraídos tinham de 2 a 3 milímetros de comprimento e diāmetro variável. Uma vez separados, foram colocados em placas de Petri esterilizadas, mergulhados em āgua esterilizada e macerados com bastão de ví dro flambado. Após a maceração, a suspensão foi deixada em repouso por cerca de 15 a 20 minutos. Passado esse período, $0,1 \mathrm{ml}$ da suspensão foram transferidos para placas de Petri contendo Wilbrink-agar (TUITE, 1969) como meio de cultura,nas quais foram riscados com auxîlio de espátula de Drigawski.

Para cada uma das suspensões preparadas foram utilizadas 10 placas que, após a riscagem, foram incubadas em estufa regula da à temperatura de $28^{\circ} \mathrm{C}$.

Com as cultivares Q 28, CP 44-101, CB 41-76 e CB 49-260, os colmos foram cortados, transportados ao laboratório e manipulados do modo já descrito. Uma vez confirmada a existencia de vasos descoloridos, trēs nós da região mediana do colmo foram cortados com cerca de 3 centimetros de comprimento e, com auxílio do expremedor manual descrito por MATSU KA (1972), deles extraiu-se o caldo, logo colocado em tubos de cultura esterilizados. A partir dos caldos assim obtidos foram preparadas diluições a $10^{-1}, 10^{-2}$ e $10^{-3}$ em àgua es- 
terilizada. Os isolamentos foram feitos plaqueando as suspen sões em meio Wilbrink - agar, procedendo-se de forma idéntica aysela utilizada anteriormente.

4.1 .2 - Identificação das bactērias isoladas de colmos de cana-de-açūcar com sintomas de RSD

As identificações das diversas bactērias obtidas dos 1solanentos foram feitas nos laboratórios de Fitopatologia da Universidade Federal Rural do Rio de Janeiro, pelos Professores Charles Frederick Robbs e Osamu Kimura.
4.1 .3 - Teste de patogenicidade das bacérias isola- das de colmos de cana-de-acúcar com sintomas de RSD

A patogenicidade das bactérias isoladas foi aferida inoculando-se plantas de cana-de-açúcar da cultivar CP 44-101 considerada como altamente suscetivel ao RSD (GILtASPIE et a 2 i , 1966). Essas plantas foram obtidas de toletes previa mente submetidos a tratamento térmico $\left(50,5^{\circ} \mathrm{C}\right.$ por 2 horas) a fim de minimizar as possibilidades de erros devidos a infec ções já existentes do agente do RSD.

As plantas-teste de CP 44-101 foram obtidas plantan do-se toletes em sacos plásticos, medindo $10 \mathrm{~cm}$ de diàmetro por $20 \mathrm{~cm}$ de altura, transparentes, com 8 furos de $0,5 \mathrm{~cm}$ di $\underline{\mathrm{s}}$ 
tribuidos na metade inferior. Esses recipientes continham mis tura de solo e compostos orgānico em proporções iguais, pre viamente esterilizada em autoclave à pressão de $1,0 \mathrm{~kg} / \mathrm{cm}^{2}$, por 2 horas. Os toletes mediam em torno de $15 \mathrm{~cm}$ de comprimento, foram plantados na vertical e exibiam de 2 a 3 gemas, dependendo do comprimento dos entre-nōs. Apenas a gema do primeiro nó superior foi conservada, eliminando-se as demais. As plantas foram cultivadas em casa-de-vegetação, com dispositivo para circulação de ar frio quando a temperatu ra atingia $30^{\circ} \mathrm{C}$. Receberam duas aplicaçoses de fertilizantes NPK $(20-20-20)$, na base de 50 mililitros por planta em so lução a 0,3\%. A primeira aplicação foi efetuada no dia do plantio e a segunda trēs semanas depois.

Com 25 dias de idade as plantas foram selecionadas pelo desenvolvimento dos brotos (7 a $15 \mathrm{~cm})$ e transferida para estrados de madeira colocados a $80 \mathrm{~cm}$ do piso, antes de submetidas à inoculação.

0 método de inoculação utilizado foi idēntico ao descrito por MATSUOKA (1972) para os testes da diagnose do RSD com capim Elefante.

Devido ao nümero relativamente pequeno de plantas se lecionadas para inoculação, o teste de patogenicidade foi mon tado com parcelas simples, sem repeticões e compostas de 12 15 plantas para cada tratamento. Os tratamentos foram aque les que constam da Tabela 1 . 
As cepas de $E$. herbicola e $P$. rubrisubalbicans empregadas, correspondem a isolados obtidos no presente traba 1ho. A cepa de $X$. albizineans foi cedida pelo Professor Dr. Hasime Tokeshi, da ESALQ/USP, Piracicaba, São Paulo e corresponde a isolado usado nos estudos sobre etiologia do RSD por TOKESHI et alii (1974).

A inclusão de dois tratamentos com $P$. rubrisubarbicans deveu-se ao fato de que foram obtidos dos isolamentos duas bactérias com características diferentes $\left(C_{2}\right.$ e $\left.C_{3}\right)$, julgando-se, a princípio, tratarem-se de espécies distintas de Pseudomonas. As identificações posteriores, todavia, revelaram que ambos os isolados pertenciam àquela espécie.

os inōculos foram preparados partindo-se de cultu ras puras dos diversos organismos com 7 dias de idade, crescen do em placas de Petri com meio de Wilbrink-agar. Dessas cul turas, preparam-se suspensões em àgua destilada e esterilizada, sendo as concentrações calibradas pela escala de Mc Far land ou com o auxîlio de espectrofotōmetro. As concentrações das suspensões foram confirmadas atravēs da contagem direta do número de colónias, após riscagem de volumes conhecidos em pla cas de cultura. o caldo bruto extraído dos nós, por meio do espremedor manual, não sofreu nenhuma diluição e foi incluído como inóculo para controle do trabalho. O segundo tratamento controle consistiu de água destilada e esterilizada.

A avaliação da patogenicidade dos diferentes orga nismos foi efetuada 45 dias após a inoculação, por meio de e- 
exames internos dos colmos, principalmente na região basal dos brotos Segundo GILLASPIE et alii (1966), as leituras de sintomas internos de RSD devem ser feitas de 4 a 6 semanas após a inoculação. Foram consideradas doentes as plantas que apresenta vam descolorações dos vasos.

Das plantas com descoloração vascular foram feitas tentativas de re-isolamento das bactérias originalmente inocu ladas pelo mesmo método utilizado nos isolamentos a partir de materiais com infecção natural.

4.1.4 - Avaliação das populações de Erwinia herbicola presentes no caldo obtido dos nós de colmos de cana-de-açūcar com sintomas de RSD

Para esse trabalho foram usadas as cultivares Q 4865 e IAC 52/326, com sintomas típicos de descoloração dos vasos na região dos nós. Foram utilizadas cinco plantas de cada cultivar, sem brocas ou rachaduras e numeradas de 1 a 5 para IAC $48 / 65$ e de 6 a 10 para IAC 52/326. As plantas eram provenientes do segundo corte ( 1 . soca) e os toletes que deram origem às touceiras tinham sido tratadas termicamente por ocasião do plantio. Très nós basais de cada colmo foram descascados assepticamente e retirados com cerca de $2,5 \mathrm{~cm}$ de com primento- 0 caldo desses nós foi extraído com o espremedor ma nual e vertido em tubos de cultura esterilizados. Para evi tar a multiplicação subsequente de bactérias, os tubos foram imediatamente imersos em àgua com gelo fundente. 
Como não se conhecia o nível populacional das bacté rias presentes na ocasião do isolamento, os caldos extraídos foram plaqueados nas diluições de $10^{-1}, 10^{-2}$ e $10^{-3}$. Com ca da diluição, foram inoculadas cinco placas contendo meio de Wilbrink - agar, pipetando-se 0,l mililitros por placa. As pla cas foram incubadas em estufa à $28^{\circ} \mathrm{C}$ e o nūmero de colónias determinado do segundo ao décimo dia.

\subsection{5 - Isolamento de bactērias de colmos de cana-de- açücar com sintomas de RSD, após o tratamento térmico dos toletes}

Como os testes de inativação tērmica "in vitro" das bactérias isoladas de cana-deraçúcar com sintomas de RSD reve laram alguma sobrevivéncia a temperaturas acima de $50^{\circ} \mathrm{C}$, pesquisou-se a possibilidade de se isolar esses microorganismos de toletes tratados termicamente. Foram coletados dez colmos de diferentes touceiras da cultivar CP 44-101, todos com sintomas de RSD, sem broca e sem rachaduras. Da base desses col mos foram obtidos toletes com trés gemas. os quais foram tra tados termicamente por 2 horas a $50,5^{\circ} \mathrm{C}$. A seguir, extraiu se o caldo dos nós sob condições assépticas, conforme descrito no item 4.1.1. O caldo obtido de cada tolete foi riscado nas diluições de $10^{-1}$ e $10^{-2}$, em placas com meio de cultura de Wilbrink-agar, usando-se cinco placas para cada diluição e $0,1 \mathrm{ml}$ de volume por placa. As placas foram incubadas em estufa $\bar{a} 28^{\circ} \mathrm{C}$ e observadas durante duas semanas. 


\subsection{6 - Ponto de inativação térmica "in vitro" das bactērias isoladas de cana-de-açūcar com sintomas de RSD}

Bactérias isoladas de canas com RSD foram submeti das a diferentes temperaturas objetivando determinar a faixa letal para cada uma delas.

De culturas puras de Xanthomonas albilineans (X RSD) e $X$. albilineans ( $X$ LSD), ambas utilizadas por TOKESHI et alii (1974), Erwinia herbicola (C 1) e Pseudomonas rubrisubalbicans ( $C 2$ e C 3 ), todas com sete dias de idade, foram prepara das suspensões em àgua esterilizada, calibrando-se as concentrações para, aproximadamente, 2,5 . $10^{8}$ células por milili tro, por espectrofotometria. De cada bactéria, foram prepara dos seis tubos contendo, cada um, 5 mililitros de suspensão. 0 tratamento térmico foi feito em banho-maria, empregando-se aparelho da marca "Scientific Precision", com precisão de $\pm 0,1^{\circ} \mathrm{C}$. Para cada temperatura a testar foi usado um dos tubos de cultura de cada bactéria. Os tubos eram de vidro, de tampa rosqueada, possuindo $7 \mathrm{~cm}$ de comprimento por $1,5 \mathrm{~cm}$ de diāmetro. As temperaturas empregadas foram $28,48,50,52$, 54 e $56^{\circ} \mathrm{C}$; o tempo de imersão dos tubos foi padronizado em 20 minutos, contados a partir do momento em que se estabele ceu equilibrio entre as temperaturas do interior do tubo e do banho. Após o tratamento os tubos foram resfriados natural mente até a temperatura ambiente. Em seguida, procedeu-se ao plaqueamento das suspensões em meio de Wilbrink-agar, pipetan do-as $0,1 \mathrm{ml}$ por placa e riscando-se com espátula de Drigawski. 
Para cada tratamento foram utilizadas cinco placas. A incuba ção teve lugar em estufa a $28^{\circ} \mathrm{C}$. As observações das placas foram realizadas do segundo até o décimo dia, pesquisando-se a ocorrēncia de colōnias típicas de cada bactéria.

0 tratamento das suspensões à temperatura de $28^{\circ} \mathrm{C}$ serviu de controle no teste, assegurando-se a viabilidade das culturas empregadas.

4.2 - Especificidade do Teste do Capim Elefante na Diagnose do RSD da Cana-de-açūcar

Para verificar a especificidade do teste de capim Elefante na diagnose do RSD de cana-de-açūcar, foram efetua dos cinco experimentos, nos quais foi empregada a metodologia descrita por MATSUOKA (1972), com algumas modificações.

Plantas de capim Elefante cultivar Merker foram desenvolvidas em sacos plásticos, medindo $10 \mathrm{~cm}$ de diāmetro por $20 \mathrm{~cm}$ de altura, transparentes, com 8 furos de $0,5 \mathrm{~cm}$ distribuĩdos na metade inferior e contendo mistura de solo e compos to orgānico, em proporções iguais, previamente esterilizada em autoclave à pressão de $1,0 \mathrm{~kg} / \mathrm{cm}^{2}$, por duas horas.

As plantas foram obtidas a partir de toletes de 2 nōs, plantadas verticalmente, enterrando-se apenas o nó inferior cuja gema foi extraída para estimular o enraizamento. Portanto, as plantas foram sempre formadas pela brotação da ge. ma do nó superior. Somente colmos ainda verdes foram escolhi 
dos para fornecimento de estacas, obtendo-se, assim, brotações mais uniformes. Os toletes foram imersos por 15 minutos em suspensão de Benomyl (Benlate) a 0,05\% de princīpio ativo.

Após esse tratamento, foram imediatamente plantados, permanecendo em casa-de-vegetação com controle parcial de temperatura $\left(20-30^{\circ} \mathrm{C}\right)$. As plantas receberam duas adubações com a för mula NPK $(20-20-20)$ na base de $50 \mathrm{ml}$ de solução a $0,3 \%$ por planta. A primeira aplicação, foi efetuada no dia do plantio e a segunda duas semanas depois. As mudas atingiram o ponto de inoculação dentre de um período de 18 a 23 dias e foram man tidas, desde o início, sobre estrados de madeira.

0 método de inoculação consistiu do corte do cartucho foliar (MATSUOKA, 1972a), com canivete previamente contaminado no inōculo. Brotações laterais, quando existentes, fo ram também inoculądas.

os canivetes e os demais instrumentos utilizados nas inoculações foram lavados e esterilizados por flambagem,à cada mudança de tratamento. Da mesma forma, as mãos foram lava das, desinfestadas com solução de Hyamine-1622 a 0,2\%, enxaguadas com àlcool e enxugadas com papel toalha à cada mudança de tratamento.

As avaliações foram normalmente procedidas 21 dias após a inoculação, mediante exames da parte interna dos col mos com cortes finos longitudinais e paralelos. Qualquer des coloração observada nos vasos foi considerada como reação positiva. 
Por questões de conveniēncia e maior clareza os delineamentos experimentais serão abordados separadamente para cada experimento.

\subsection{1 - Reação do capim Elefante à inoculação com al- gumas bactērias fitopatogēricas}

Face ao fato de que $X$. albizineans é capaz de induzir descoloração vascular em capim Elefante, TOKESHI et alii (1974), testou-se a hipótese de que outros microorganismos fi topatogēnicos pudessem provocar reações semelhantes nessa plan ta-teste. Foram investigadas as espécies de bactérias apre sentadas na Tabela 2 , procedentes de diversas instituições, sendo que aquelas tidas como patogēnicas à cana-de-açūcar foam utilizadas especialmente para controle do trabalho.

Culturas puras das bactérias foram desenvolvidas por 7 dias em placas com meio de Wilbrink-agar. As suspensões bactérianas preparadas dessas culturas foram padronizadas pela escala de Mc Farland para uma concentração correspondente a $10^{8}$ células de Bacizzus subtizis por mililitro.

0 delineamento experimental foi o de blocos ao acaso com 11 tratamentos, 3 repetições e 20 plantas por parcela. Os toletes foram plantados em $18 / 03 / 75$, as plantas inocula das em 07/04/75 e os resultados avaliados em 28/04/75. 
4.2.2 - Reação do Capim Elefante à Inoculação com Bactérias e Fungos Ísolados de Cana-de-açūcar e Leveduras Encontradas em Destilarias de Aguardente de Cana-de-açūcar

Desse experimento fizeram parte trēs espécies de bac térias isoladas de cana-de-açūcar com sintoma de RSD: E. her bicola (C I), P. rubrisubalbicans (C 2 e C 3) e X. albilineans (X RSD). Os fungos testados foram Colzetotrichum falcatum e Fusarium moniliforme, que causam prejuizos em praticamente to das as regiões onde a cana é cultivada. Foram utilizadas trēs cepas de F. moniliforme: C 17 , C 24 e C 29 reveladas como as mais patogénicas pelo trabalho de EIRA (1972), de quem as cul turas foram obtidas. As espécies de leveduras incluídas foram aquelas encontradas com maior frequência nas destilarias de aguardente de cana-de-açūcar no Estado de São Paulo, NEDER (1957). Os tratamentos e origem dos materiais que constituem o ensaio encontram-se na Tabela 3.

Com relação as leveduras, parece lícito supor que possam ocorrer também com frequência em canaviais e que pos sam, portanto, contaminar eventualmente o caldo por ocasião de sua extração e interferir no resultado do teste em capim E lefante para diagnose do RSD.

Para os fungos e as leveduras, a concentração dos $\underline{i}$ nóculos foi de, aproximadamente, $10^{6}$ talos por mililitro, ten do sido determinada com o auxîlio do hemacitōmetro.

As concentrações das suspensões bacterianas foram ca libradas usando-se colorímetro Bausch \& Lomb, modelo Spectronic-20, ajustando-se para $75 \%$ de transmitāncia, com compri - 
mento de onde de 580 nanómetros. Fazendo-se o plaqueamento, apōs essa calibragem, pelo processo de diluição em sērie, verificou-se que a concentração era de 2,5 . $10^{8}$ células viáveis por mililitro para E. herbicola (C 1). Entretanto, para outras bactērias, inclusive $X$. albilineans ( $X$ RSD), não foi pos sĩvel determinar a concentração com precisão, uma vez que à diluição $10^{-5}$, nenhuma colónia se desenvolvia ao passo que à $10^{-4}$ tornava-se impraticāvel proceder à contagem devido a um nümero excessivo de colōnias formadas. Diante dessa dificuldade optou-se por utilizar os dados de Fujio Akiba (comunicação pessoall), que estimou em 8 . 10 células por mililitro, a concentração de $X$. aZbizineans na escala 3 de Mc Farland.

0 esquema experimental empregado foi o de blocos ao acaso, com 15 tratamentos e 3 repetições, com 12 plantas por parcela. Os, toletes de capim Elefante foram plantados em $03 /$ 05/1975, as plantas inoculadas em 26/05/75 e a avaliação final feita em 16/06/1975. Para controle do trabalho, utilizouse àgua destilada e esterilizada como um dos tratamentos.

4.2.3 - Reação do Capim Elefante à Fusarium moniziforme, Candida cruzei, Hansenula anomala e Saccharomyces cerevisiae, inoculados em diferentes concentracões

A razão principal de se efetuar esse experimento foi de que em estudo anterior ficou patenteado que tanto o Fusarium como algumas leveduras, eram capazes de provocar intensa 
reação de descoloração vascular no capim Elefante, quando ino culados em concentrações elevadas.

Partindo-se de suspensões de C. cruzei, F. monizí forme, H. anomala e $S$. cerevisiae com $10^{6}$ talos por milili tro, fez-se diluições sucessivas em água esterilizada até $10^{1}$ talos por mililitro. As parcelas testemunhas foram tratadas com āgua esterilizada. Os tratamentos que constituiram o ensaio encontram-se na Tabela 4.

0 esquema experimental foi o de blocos ao acaso com 13 tratamentos e 3 repetições, com as parcelas formadas por 12 plantas. Os toletes de capim Elefante foram plantados em 04/07/1975, as plantas inoculadas em 26/07/1975, e a avalia ção final do experimento realizada em 21/08/1975.

4.2.4 - Reação do Capim Elefante à Inoculação com Baç tērias Isoladas de Cana-de-açūcar com Sinto mas de RSD, em Diferentes Concentrações

Os tratamentos incluĩdos nesse teste são apresentados na Tabela 5. As suspensões bacterianas foram calibradas para concentrações de $10^{3}$ e $10^{4}$ células viáveis por mililitro em água destilada e esterilizada.

os esquema experimental foi o de blocos ao acaso com 11 tratamentos e 3 repetições com as parcelas formadas por 12 plantas. Os toletes de capim Elefante foram plantados em $06 /$ $08 / 75$, as planta inoculadas em $27 / 08 / 75$ e a avaliação final do teste realizada em 18/09/75. 
4.2.5 - Reação do Capim Elefante ao Caldo Extraído e ás Bactérias Isoladas de Colmos de Cana-de açūcar com Sintomas de RSD, Submetidas ou não à Inativação Térmica

Para essa investigação, utilizou-se a cultivar CP 44-101, de primeiro corte e com 15 meses de idade. 0ito to letes de trēs gemas foram obtidos de plantas selecionadas; qua tro destes foram tratados termicamente em água quente a $50,5^{\circ} \mathrm{C}$, durante 2 horas. Todos os toletes (tratados ou não tratados termicamente) foram raspados, mergulhados em ālcool, flamba dos em fogo direto, descascados e separados os nós, dos quais foi extraído o caldo com espremedor manual, de acordo com MAT SUOKA (1972a). Os instrumentos usados foram esterilizados por flambagem para eliminar os possíveis contaminantes. Os cal dos obtidos foram vertidos em tubos de cultura esterilizados, sendo que o caldo extraído dos toletes não tratados termica mente foi dividido em duas aliquotas, sendo uma delas submeti da a tratamento térmico.

Os caldos foram aplicados sem diluição, enquanto que a concentração das suspensões bacterianas foi calibrada pela escala 3 de Mc Farland. A inativação dos organismos foi processada colocando-se $10 \mathrm{ml}$ do caldo e das suspensões bacte rianas em tubos de vidro com tampa rosqueada (medindo $10 \mathrm{~cm}$ de comprimento por $1,5 \mathrm{~cm}$ de diàmetro) e mergulhando-os completa mente em āgua a $60^{\circ} \mathrm{C}$, durante 25 minutos. Os tratamentos em pregados no experimento estão na Tabela 6. 
o delineamento experimental foi o de blocos ao acaso com 11 tratamentos, 3 repetições, sendo as parcelas compos tas de 10 plantas. 0 plantio dos toletes de capim Elefante foi realizado em $15 / 11 / 75$, a inoculação das plantas efetua da em 03/12/75 e a avaliação final do teste feita em 27/12/75. 
5 - RESULTADOS

5.1 - Isolamento de Bactérias dos Colmos de Cana-de-Açūcar com Sintomas de RSD

5.1.1 - Caracteristicas das Bactérias Isoladas dos Col mos de Cana-de-açūcar com Sintomas de RSD

Da cultivar IAC 52/326, primeiro material utilizado, os isolamentos a partir de vasos descoloridos da região nodal produziram colōnias bacterianas de très tipos distintos que surgiram em todas as placas.

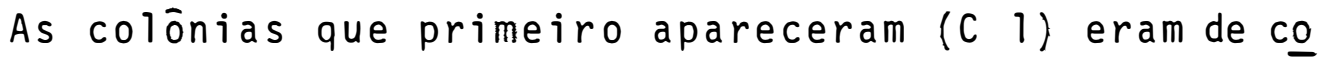
loração amarelo-claro, convexas, circulares, de bordos lisos, cheiro ativo e crescimento muito rápido no meio de cultura. Aquelas surgidas 5 dias após o plaqueamento eram claras, bran cas, circulares, tinham crescimento lento, sendo algumas de 
bordos lisos ( $\left(\begin{array}{l}\text { 2) e outras de bordos irregulares ( } \\ \text { ( } 3 \text { ). Des }\end{array}\right.$ tes trēs tipos de colónias foram obtidas culturas puras. A quantidade de colónias do tipo $C 1$, era sempre bem maior em relação aos outros dois tipos ( C 2 e C 3 ).

Os isolamentos obtidos das cultivares Q 28 e CP 44101 , plaqueando-se o caldo extraîdo dos nōs, produziram colónias idēnticas às obtidas da cultivar IAC 52/326. As do tipo C 1 ocorreram em todas as placas, incluindo aquelas inocula das com caldo diluído a $10^{-3}$. Colónias do tipo C 2 e C 3 ocorreram principalmente nas placas inoculadas com caldo diluI do a $10^{-1}$. Nas placas inoculadas com caldo não diluído o nú mero de colónias do tipo C I foi tão elevado que não permitiu distinguir qualquer outro tipo de colónia. Nas placas inoculadas com diluição a $10^{-3}$, sō apareceram colónias do tipo $C 1$ ( 3 a 8 colónias por placa).

Nas placas de isolamento correspondentes às cultiva res CB 41-67 e CB 49-260, cresceram apenas colōnias do tipo c 1 e em quantidade bastante reduzida.

Assim, bactērias formando colōnias do tipo C 1 foram isoladas de todas as plantas e de todas as cinco cultivares testadas, o mesmo não ocorrendo com relação àquelas per tencentes aos tipos C 2 e C 3 . 
5.1.2 - Identificação das Bactērias Isoladas de Colmos de Cana-de-açūcar com Sintomas de RSD

Do relatōrio de identificação das bactērias,fornecido pelo Professor Charles F. Robbs e Osamu Kimura, conclui-se que a bactéria produzindo colónias do tipo C I era Erwinia herbicola (Lohnis) Bye, de acordo com os resultados de testes bioquímicos e culturais empregados na diferenciação dos trēs grupos ("Amylovora" , "Herbicola" e "Caratovora") que compõem esse gēnero (LELLIOT, 1974). Alguns desses testes serviram pa ra. enquadrar o organismo como Erwinia herbicola var. herbico$Z a$, distinguindo-se de E. herbicola var. ananas, E. stewartii e $E$. uredovora que, juntos, constituem o grupo "Herbicola". Aquelas formando colónias de tipo $C 2$ e $c 3$ foram idenficadas como Pseudomonas rubrisubalbicans (Christopher e Edgerton) Krasil'nikov (sensu Hale e Wilkie, 1972). Esse organismo foi negativo para atividade lipolítica, produziu ácido de lactose em meio de HAYWARD (1962) e utilizou malonato ou tartarato como fontes únicas de carbono para crescimento, características essas que o distinguem de $P$. rubrizineans, agen te causal das estrias vermelhas da cana-de-açūcar.

5.1.3 - Testes de Patogenicidade das Bactérias Isoladas de Colmos de Cana-de-Açúcar com Sintomas de RSD

Os resultados do teste de patogenicidade das bactērias isoladas de cana-de-açūcar com sintomas de RSD, encon - 
tram-se na Tabela 7.

Plantas inoculadas com caldo bruto e E. herbicola ( $C$ 1), mostraram acentuada descoloração dos vasos da região ba sal da brotação. Nas plantas inoculadas com Pseudomonas ru brisubalbicans ( C 2), P. rubrisubalbicans (C 3) e Xanthomo nas albilineans ( $X$ RSD), os sintomas foram bem menos intensos, tanto no grau de descoloração como no número de vasos descolo ridos. Os tratamentos mais eficientes foram o caldo bruto e E. herbicola ( C 1), produzindo resposta positiva em $100 \%$ e $73 \%$ das plantas inoculadas, respectivamente. P. rubrisubalbicans (C 2 e C 3) situou-se como intermediāria entre E. herbicola (C 1) e X. albilineans (X RSD) na indução de descoloração vacular em cana-de-açūcar.

Reisolamentos foram obtidos apenas para $E$. herbicoIa (C I) sendo que para $P$. rubrisubalbicans ( $C 2$ e C 3 ) e $X$. albilineans ( $X$ RSD) as tentativas foram negativas. Das plantas inoculadas com caldo bruto foi possivel o isolamento de bactérias com as mesmas características de $E$. herbicola.

5.1.4 - Avaliação das Populações de E. herbicola Presentes no Caldo obtido nos nós de colmos de Cana-de-açúcar com Sintomas de RSD

Nas placas inoculadas com caldo não diluído e diluí do a $10^{-1}$, o nūmero de colónias de E. herbicola foi demasiado elevado impossibilitando a contagem. Nas placas com dilui ção de $10^{-2}$, a té o quinto dia foi possivel contar colónias in 
dividuais, tornando-se impraticável a contagem apōs esse período devido à coalescência das colōnias. As placas mais ade quadas para contagem de colónias da bactéria foram aquelas ino culadas com a diluição de $10^{-3}$.

Resultados satisfatórios foi obtido para quatro plan tas da cultivar IAC $48 / 65$ e para trés plantas da cultivar IAC 52/326. Nos demais casos houve contaminação das placas, prin cipalmente com Fusarium spp.

A avaliação final do nūmero de colónias de $E$. herbi cola ( 1 1) nas placas inoculadas com caldo diluído a $10^{-3}$, en contra-se na Tabela 8. As populações do organismo, variaram entre $1,2 \cdot 10^{5}$ e 2,8 $\cdot 10^{5}$ células viáveis por mililitro de cal do na cultivar IAC 48/65 e entre 0,7.106 e 3,8.106 células viāveis por mililitro de caldo, na cultivar IAC 52/326. Assim, nas 4 plantas avaliadas da cultivar IAC $48 / 65$ registraram-se popula . ções em torno de $10^{5}$ células viāveis por mililitro, enquanto que na cultivar IAC 52/326 as populações atingiram níveis bem mais altos. Colōnias idênticas às de $P$. rubrisubarbicans ( $C 2$ e C 3 ) apareceram em número reduzido nas placas inoculadas com caldo diluído até $10^{-3}$. No entanto, não foi possível fazer a contagem dessas colónias, pois as placas foram rapidamente to madas pelo crescimento de E. herbicola (C 1).

5.1.5 - Isolamento de Bactérias de Colmos de Cana-deaçūcar com Sintomas de RSD, apōs o Tratamento Térmico dos Toletes

Nas placas inoculadas com caldo diluĩdo a $10^{-2}$, não 
se constatou crescimento de qualquer tipo de bactēria. Em to das as placas inoculadas com caldos originārios de 10 plantas, diluídos a $10^{-1}$, formaram-se colónias de E. herbicola (C I) mas nenhuma de $P$. rubrisubarbicans ( 2 ou $C 3$ ). Em uma das plantas, notou-se, apōs 7 dias, a presença de pequeninas coló nias idēnticas às de $X$. arbizineans ( $X$ RSD). Tais colónias $\underline{e}$ ram transiúcidas, brilhantes, lisas, de crescimento lento e ocorriam em grupos, muito próximas umas das outras.

A fim de se comparar essa ūitima bactéria com $X$. a bilineans (X RSD), isolada e estudada por TOKESHI et alii (1974), tentou-se obté-la em cultura pura a partir do material inoculado. Essas tentativas, todavia, foram infrutiferas pela invariável interferéncia de $E$. herbicola nas placas de iso lamento e pela incapacidade de fazer crescimento sobre o meio utilizado.

5.1 .6 - Ponto de Inativação Térmica "in vitro" das Bac térias Isoladas de Cana-de-açūcar com Sintomas de RSD

os resultados do teste para verificar o ponto de inativação térmica "in vitro" das bactérias isoladas de cana de-açūcar com sintomas de RSD, encontram-se na Tabela 9. Nenhuma das bactērias resistiu ao tratamento por imersão em $\bar{a}-$ gua quente à temperatura de $56{ }^{\circ} \mathrm{C}$ durante 20 minutos. As temperaturas de $48^{\circ} \mathrm{C}$ e de $50^{\circ} \mathrm{C}$ foram suficientes para inativar 
completamente $P$. rubrisubalbicans ( $C 2$ e C 3 ) e $X$. albilineans (X LSD), respectivamente. E. herbicola (C I) resistiu a $52^{\circ} \mathrm{C}$ mas foi totalmente inativada a $54^{\circ} \mathrm{C} . X$. albilineans (X RSD), apesar de resistir às temperaturas de $52^{\circ} \mathrm{C}$ e $54^{\circ} \mathrm{C}$, produziu colónias em nümero consideravelmente menor do que aquele registrado a partir de suspensões submetidas a temperaturas mais baixas .

5.2 - Especificidade do Teste de Capim Elefante na Diagnose do RSD de Cana-de-açūcar

5.2.1 - Reação do Capim Elefante à Inoculação com Algumas Bactērias Fitopatogénicas

Os resultados relativos às observações de descolora ção vascular apōs inoculação do capim Elefante com algumas bac térias fitopatogēnjicas, encontram-se na Tabela 10.

A anālise de variāncia mostrou diferenças altamente significativas entre tratamentos. Os tratamentos representados pelas bactērias E. herbicola (ENA 2041) , E. herbicola (ENA 2130) e X. phaseoli, não diferiram da testemunha (água esterilizada). Contudo, E. herbicola (ENA 2041) e E. herbicola (ENA 2130) não diferiram também dos tratamentos classificados em segundo lugar, o que não aconteceu em relação a $X$. phaseoli. Assim, todas as bactérias inoculadas, com exceção da $x$. phaseoli, foram capazes de provocar sintomas internos quando ino 
culadas em capim Elefante. As cepas de X. aZbizineans (X LSD e X RSD) foram capazes de provocar reação positiva em todas as plantas inoculadas.

5.2.2 - Reação do Capim Elefante à Inoculação com Bactérias e Fungos Isolados de Cana-de-açūcar e Leveduras Encontradas em Destilarias de Aguardente de Cana-de-açūcar

Os resultados das inoculações em capim Elefante com bactērias e fungos isolados de cana-de-açūcar e com leveduras mais comumente encontradas nas destilarias de aguardente de ca na, encontram-se na Tabela 11.

A anāilise de variāncia mostrou diferenças altamente significativas entre tratamentos. Os tratamentos com cozzeto trichum falcatum, Candida tropicalis, Schizosaccharomyces pombae e Saccharomyces carlsbergensis, não diferiram da testemunha não tratada. Os demais tratamentos diferiram da testemunha, podendo-se daí concluir que induzem reação positiva de descoloração de vasos por inoculação em capim Elefante.

5.2.3 - Reação do Capim Elefante à Fusarium moniziforme, Candida cruzei, Hansenula anomala e sac charomyces cerevisiae, Inoculados em Diferentes Concentrações

Os resultados das inoculações em capim Elefante com 
F. moniliforme, C. cruzei, H. anomala e S. cerevisiae, em di ferentes concentrações, encontram-se na Tabela 12.

A anāilise de variāncia mostrou diferenças altamente significativas entre tratamentos. Todos os tratamentos nas concentrações máximas induziram alto número de plantas com sin tomas internos. Mesmo em concentrações relativamente baixas (5 a $7.10^{2}$ células viáveis por mililitro), todos os tratamen tos empregados diferiram da testemunha e devem ser considerados como capazes de provocar descoloração dos vasos quando inoculados em capim Elefante.

5.2.4 - Reação do Capim Elefante à Inoculação com Bactérias Isoladas de Cana-de-açūcar com Sintomas de RSD, em Diferentes Concentrações

Os resultados das inoculações em capim Elefante com bactērias isoladas de cana-de-açūcar com sintomas de RSD, em diferentes concentrações, encontram-se na Tabela 13.

A anālise de variāncia mostrou diferenças altamente scroficativas entre tratamentos. Todos os tratamentos a con centrações iguais ou superiores a $2,5 \cdot 10^{3}$ células viáveis por mililitro, foram capazes de provocar reação positiva em capim Elefante, com exceção de P. rubrisubalbicans (C 2) e P. rubrisubalbicans ( $C$ 3) que só provocaram essas reações quando í noculadas em concentrações iguais ou superiores a $2,5 \cdot 10^{4}$ cé ulas viāveis por mililitro. 
5.2.5 - Reação do Capim Elefante ao Caldo e às Bactérias Isoladas de Colmos de Cana-de-açūcar com Sintomas de RSD, Submetidos ou não à Inativa ção Térmica

Os resultados das inoculações em capim Elefante com os caldos extraîdos e com as bactérias isoladas de cana-de-açū car com sintomas de RSD, submetidas ou não ao tratamento tér mico, encontram-se na Tabela 14.

A anālise de variāncia mostrou diferenças altamente significativas entre tratamentos. Todos os tratamentos subme tidos a $60^{\circ} \mathrm{C}$ não produziram reação no capim Elefante, ao passo que todos os tratamentos representando bactērias vivas em suspensão provocaram pronta reação. O caldo bruto, quando inoculado em estado natural, não diferiu dos tratamentos constituīdos de culturas de bactérias vivas, mas quando tratado a $60,0^{\circ} \mathrm{C}$ mostrou-se inócuo. Quando tratado a $50,5{ }^{\circ} \mathrm{C}$, no en tanto, o caldo bruto foi capaz de induzir reação em $50 \%$ das plantas inoculadas. 
$6-$ DISCUSSAOO

Inicialmente serão discutidos os resultados referen tes à caracterização das bactērias isoladas de plantas de cana-de-açūcar com sintomas de RSD, seguindo-se os resultados dos experimentos destinados a aferir a validade do teste com capim Elefante na diagnose da doença.

6.1 - Caracterização de Bactērias Associadas ao RSD da Cana-de-açūcar

A bactēria isolada de cana-de-açūcar com sintomas de de RSD e identificada como Erwinia herbicola, revelou-se pre sente em todas as cultivares testadas, quais sejam: IAC 52/ $326, Q 28, C P 44-101, I A C 48 / 65, C B 41-76$ e CB 49-260. 0 organismo identificado como Pseudomonas rubrisubalbicans foi encontrado em todas as cultivares suscetiveis ao RSD, não ten do sido recuperado, contudo, de cultivares suscetíveis à mo- 
léstia CB 41-76 e CB 49-260. As mesmas bactérias foram obtidas tanto pelo método de isolamento a partir de vasos descolo ridos, como pelo método de extração do caldo dos nós por espremedura.

0 isolamento de bactérias com características de $X$. arbilineans X RSD (TOKESHI et alii, 1974), sõ foi conseguida em uma ūnica oportunidade e, coincidentemente da mesma cultivar (CP 44-101) por eles trabalhada.

Quando GILLASPIE JR. et alii (1973), TEAKLE et alii (1973), Gillaspie JR. (1974), TEAKLE (1974) e WORLEY e GilLASPIE JR. (1975) demonstraram a associação de bactérias com canas apresentando sintomas de RSD, é possível que estivessem lidando com os organismos agora constatados.

A espécie Erwinia herbicola (Lohnis) Dye possui duas variedades reconhecidas. A primeira delas é E. herbicola var. ananas, agente causal de uma podridão ("pink disease") de frú tilhos de abacaxi, recentemente estudado por CHO et alii (1973). A segunda variedade é designada como E. herbicola var. herbicola. A questão da patogenicidade da var. herbicoZa ainda não está completamente elucidada. Segundo GIBBINS (1978), hā evidências de que esse organismo pode estar envolvido tanto na alteração da predisposição de plantas ao ataque de patógenos, como na modificação da virulēncia e da atividade de bactérias fitopatogênicas "in situ".

Embora primariamente tidas como saprófitas, estir pes de $E$. herbicola têm sido diretamente implicados em doenças 
de plantas. CROSSE (1971) considera que organismos do grupo de E. herbicola sejam componentes importantes de complexos cau sais de enfermidades sob condições naturais. Bactérias reconhecidas como fitopatogennicas e hoje na sinonimia de E. herbi cola var. herbicola, são: E. Zathiri, que incita doença em Lathyrus spp. (GRAHAM, 1958), E. milletiae, responsāvel por galhas em "Millet" (SUZUKI e UCHIDA, 1965) e o agente causal da necrose interna ("Boll Rot") de maçãs do algodoeiro (ASCODLAY et alii, 1970).

A par dessas citações, E. herbicola é considerada co mo forma predominante da microflora residente em superficies vegetais (saprōfita) (GIBBINS, 1978) e é frequentemente isolada de tecidos de plantas doentes, algumas vezes atingindo populações consideravelmente elevadas (ZUET, 1969). Nos últi mos anos, representantes do grupo "Herbicola" tèm sido asso ciados a problemas de ordem médico e veterināria (GIBBINS, $1978)$.

A literatura universal sobre $E$. herbicola foi recen temente revista por SANHUEZA (1979) e inclui outros autores não relacionados ou comentados na presente dissertação.

A espécie Pseudomonas rubrisubazbicans (Christopher e Edgerton) Krasil'nikov 1949 foi retida como espécie vālida na recente proposição de YOUNG et alii (1978) sobre classificação e nomenclatura de bactérias fitopatogénicas.

Essa espécie faz parte de um grupamento de Pseudomo nas fitopatogénicas caracterizadas por se apresentarem como 
não fluorescentes e por acumularem poli- $\beta$-hidroxibutirato co mo substāncia de reserva (DOUDOROFF e PALLERONI, 1974).

Estudo comparativo entre espécies de Pseudomonas pa togēnicas ao sorgo (HALE e WILKIE, 1972), permitiu separā-las na base de um conjunto: de características morfológicas, cultú rais e bioquímicas. Usando o esquema proposto pelos autores acima, P. rubrisubalbicans pode ser diferenciado claramente de P. rubrizineans, que causa as estrias vermelhas da cana-de-a çūcar.

P. rubrisubalbicans foi originalmente descrita como responsāvel pela doença designada de "Mottled Stripe", descrí ta sobre cana-de-açūcar na Louisiana, E.U.A. (CHRISTOPHER e EDGERTON, 1930). E, tambēm, patogēnica ao sorgo quando inocú lada artificialmente (HALE e WILKIE, 1972).

os resultados contidos na Tabela 7 , indicam que tan to E. herbicola como $P$. rubrisubalbicans são patogēnicas à cana-de-açūcar, ambos capazes de infectar a cultivar CP 44-101, recomendanda por GILLASPIE JR. et alii (1966) e por IRWINE (1976), para diagnose do RSD. Os testes de patogenicidade, $\underline{e}$ videnciaram, ainda, que tanto E. herbicola como P. rubrisubal bicans não sendo patógeno específico do sistema vascular, de vem induzir maior reação de defesa e descoloração vascular. A X. albilineans, sendo sistêmica e adaptada ao xilema deverá produzir maior infecção porém, com menor intensidade de descoloração vascular. 
0 fato de que todas as plantas inoculadas com o cal do extraído dos nós de indivíduos com RSD mostraram sintomas, demonstra a adequabilidade do uso da cultivar CP 44-101 para o teste, assim como indica a eficācia do método de inoculação empregado. Mostra, também, que caldo de plantas doentes deve conter algum componente ou fator que acelera ou acentua a rea ção da planta inoculada ao agente do RSD. Como GILLASPIE JR. et alii (1966) e IRWINE (1976) não trabalharam com inōculos porvenientes de culturas bacterianas puras, não puderam notar certas influéncias que por ventura poderiam estar ocorrendo. Por outro lado, é possível que, se a leitura dos testes de pa togenicidade usando culturas. puras tivessem sido efetuada aos 90 dias, conforme TOKESHI et alii (1974) o fizeram, todas as plantas inoculadas apresentassem reação positiva.

P. rubrisubalbicans não pôde ser reisolada de plantas inoculadas. Com relação a isso, é possível que tenha ocorrido problema anālogo àquele verificado por ocasião da calibragem do inōculo através do plaqueamento de diluições sucessivas. Durante essa calibragem notou-se que a bactéria de senvolvia-se muito bem até a concentracão de $10^{4}$ células por mililitro, enquanto que a $10^{3}$ células por mililitro a viabili dade caía a zero, com auséncia total de colónias no meio semeado (item 4.2.2). Portanto, é provāvel que na ocasião do reisolamento a concentração da bactéria, na suspensão obtida após a maceração dos tecidos afetados, ten-a atingido níveis excessivamente baixos que não permitiram sua recuperação pelo 
mētodo empregado.

os plaqueamentos realizados visando a determinar a população de bactérias na região nodal de plantas com sinto mas de RSD, mostraram que estas são bastante altas nas cultivares suscetiveis, conforme se pode constatar pelos dados da Tabela 8. Nas cultivares IAC $48 / 65$ e IAC $52 / 326$ as populações de $E$. herbicola, foram bem mais elevadas do que em outras cul tivares suscetiveis, $Q 28$ e CP 44-101. Nestas duas ūitimas cultivares, as populações da bactéria não ultrapassaram $10^{4}$ células viāveis por mililitro de caldo. Tal diferença pode ter ocorrido em decorréncia da idade das touceiras, pois as as touceiras de IAC $48 / 65$ e IAC $52 / 326$ provieram de cana soca enquanto que as das duas outras cultivares eram, ainda, de ca na planta.

Apesar de que as canas da cultivar Q 28 foram prove nientes de touceiras cujos toletes matrizes havim sido tratadas termicamente, não houve diferenças na população das bactê rias, em relação à cultivar CP 44-101 proveniente de material propagativo que não recebeu o tratamento térmico.

Nas cultivares consideradas suscetiveis, CB 4l-76 e CB 49-260, as populações bacterianas nunca foram superiores a $10^{3}$ células viāveis por mililitro de caldo. Esses dados indi cam que em cultivares suscetíveis existem mecanismo de defesa que restringem as populações de bactérias na região nodal, ao passo que em cultivares altamente suscetíveis há maior proliferação desses microorganismos a ponto de prejudicar o desen- 
volvimento das plantas. Corroborando essa hipótese, BAILEY (1977) e VALARINI (1978), mostraram que, realmente, em plantas severamente afetadas pelo RSD, o fluxo d'água pelos vasos do colmo foi drasticamente reduzido, enquanto que nas cultivares mais tolerantes a redução do fluxo não foi tão acentuada. Is to parece demonstrar que a alta concentração de bactérias nos colmos de cultivares suscetíveis contribui para a obstrução dos vasos, impedindo o fluxo normal da ägua. Com base nos re sultados descritos, pode-se concluir que quando a planta é afetada pelo agente do RSD, a redução no crescimento vegetativo que se verifica é em função da má circulação da seiva atra vés dos vasos.

Se no sistema vascular de plantas doentes os indices de crescimento das populações das bactērias forem comparáveis àqueles observados "in vitro", os danos causados por $E$. herbi cola seriam bem maiores do que aqueles devido a $P$. rubrisu balbicans ou $X$. albilineans (X RSD). Entretanto, podem ocorrer fatores de estimulo nas plantas que façam com que tanto P. rubrisubalbicans como $X$. albilineans (X RSD) multipliquemse mais intensamente "in situ", acarretando prejuizos ao desenvolvimento das touceiras atacadas. Segundo SANHUEZA (1979), E. herbicola estimula a multiplicação de $X$. albilineans, ao passo que inibe a de Pseudomonas sp. Por outro lado, Pseudomonas sp. inibe o crescimento de $X$. albizineans. Com base nos dados de SANHUEZA (1979), era de se esperar que, $X$. albi 
Zineans fosse isolada com frequéncia de material com RSD, 0 que na realidade não ocorreu durante a presente pesquisa.

os isolamentos efetuados apōs o tratamento térmico dos toletes a $50,5^{\circ} \mathrm{C}$ por duas horas, demonstrando que esse tra tamento teve eficiēncia apenas parcial para eliminação de $E$. herbicola, ao passo que se mostrou totalmente eficaz para $P$. rubrisubarbicans.

Observando os dados da Tabela 9 , referente aos testes em que as bactērias foram submetidas a diferentes tempera turas "in vitro", pode-se constatar que, realmente, E. herbico Za é mais resistente ao tratamento térmico, tolerando tempera turas de ate $52^{\circ} \mathrm{C}$.

os resultados obtidos indicam uma das razões do apa recimento de plantss com RSD quando provenientes de colmos tra tados, antes do plantio, com temperaturas abaixo de $52^{\circ} \mathrm{C}$, con forme relatam EL-BANNA e MOURSI (1967), LOPES-ROSA e ADSUAR (1970), MATSUOKA (1972a) e GALLI et arii (1980).

Levando em consideração o fato de que $P$. rubrisubaz bicans pode ser facilmente inativada pelos tratamentos térmi cos convencionais, bem como os resultados de TOKESHI et alii (1974), parece haver boas evidéncias de que $E$. herbicola e X. albizineans constituem espécies bacterianas envolvidas na etiologia do RSD da cana-de-açūcar. 
6.2 - Validade do Teste com Capim Elefante para Diagnose do RSD da Cana-de-açūcar

Os resultados obtidos revelaram que o capim Elefante, recomendado por MATSUOKA (1971, 1972a e 1972b) como planta indicadora na diagnose do RSD, não deve ser utilizado para tal finalidade.

Os dados da Tabela 10, mostram que o capim Elefante reage com os mesmos sintomas de descoloração dos vasos da região nodal quando inoculado com suspensões de diversas bactérias, dentre as quais Pseudomonas rubrizineans, agente das estrias vermelhas da cana-de-açūcar; Xanthomonas azbizineans, agente da escaldadura da cana-de-açūcar ; Erwinia carotovora, causadora de podridões moles em grande número de hospedeiros, e $P$. mori incitante da mancha bacteriana da amoreira. Dentre as bactérias testadas, somente $X$. phaseozi, agente do crestá mento bacteriano do feijoeiro, não induziu reação positiva. Esses dados confirmaram aqueles anteriormente obtidos por BET TI et alii (1976) que conseguiram produzir sintomas de descoloração dos vasos em capim Elefante após inoculações com vārias outras bactérias.

Pelos resultados contidos na Tabela 11 , verifica-se que diversos fungos e leveduras são também capazes de induzir reações semelhantes no capim Elefante. Neste grupo destaca ram-se Fusarium moniliforme, Candida cruzei, Hansenula ano mala e saccharomyces cerevisiae. Por outro lado, as plantas não reagiram às inoculações com $S$. carlsbergensis, Schizosa- 
ccharomyces pombe, C. tropicalis e Colletotrichum falcatum.

Em relação a F. moniliforme, C. cruzei, H. anoma Za e S. cerevisiae o capim Elefante mostrou-se altamente sen sỉvel, reagindo positivamente mesmo com concentrações de inōculo da ordem de $5.10^{1}$ talos por mililitro (Tabelas 11 e 12). A resposta do capim Elefante é, também, bastante nítida para as espécies $E$. herbicola (C I) e P. rubrisubalbicans ( $C_{2}$ e C 3), isoladas de cana-de-açūcar com sintomas de RSD. As plan tas reagem mais intensamente e em maior frequencia com as con centrações mais altas dos inōculos dessas bactérias $\left(2,5,10^{8}\right.$ células viáveis por mililitro). No entanto, ainda reagem, em bora em menor frequēncia, com concentrações de $2,5 \cdot 10^{4}$ cēlulas viāveis por mililitro para $P$. rubrisubalbicans (C 2 e C 3 ) e de $2,5 \cdot 10^{3}$ células viāveis por mililitro para E. herbicola ( $\left.\begin{array}{ll}C & 1\end{array}\right)$.

Analisando comparativamente os dados das Tabelas 10, 13 e 14 , observa-se que há diferenças na capacidade de induzir reação em capim Elefante entre as cepas de $E$. herbicola. As cepas de E. herbicola (ENA 2041) isolada da bananeira e de E. herbicola (ENA 2130) isolada do guaraná, mesmo quando inoculadas na concentração de $10^{8}$ células viáveis por mililitro, induziram respostas positivas em menor frequéncia do que a ce pa de $E$. herbicola ( C I) isolada da cana-de-açūcar na concentração de $2,5 \cdot 10^{3}$ células bacterianas por mililitro. Os resultados demonstraram ainda que o capim Elefante reage muito bem para $X$. albizineans ( $X$ RSD) inoculada em concentrações a 
tas.

Os dados da Tabela 14, mostram que todos os inōculos tratados a $60^{\circ} \mathrm{C}$ perderam a capacidade de induzir reação no ca pim Elefante. Isso vem confirmar que o que realmente provoca essa reação são os componentes vivos de cada inóculo. Ficou ainda comprovado que o tratamento térmico a $50,5^{\circ} \mathrm{C}$ não elimina por completo o patógeno presente no caldo bruto extraído de canas doentes, visto que $50 \%$ das plantas de capim Elefante reagiram positivamente. 
58.

7 - CONCLUSOES

os resultados obtidos permitem formular as seguin tes conclusões:

a - 0 teste do capim Elefante revelou-se inespecífico para a bactēria do RSD, dando reações positivas para diversas bactērias, fungos e levedurás;

b - O teste do capim Elefante não deve ser usado para o diag nóstico do raquitismo das soqueiras (RSD);

c - A bactéria Erwinia herbicola está constantemente associa da com cana-de-açūcar apresentando sintomas de RSD, ocor rendo em niveis populacionais elevados na região vascu lar de colmos provenientes de touceiras doentes;

d - Com base nos testes bioquímicos "in vitro", este é o pri meiro relato de ocorrēncia de Pseudomonas rubrisubalbicans causando infeç̧ão sistēmica na cana-de-açūcar; 
e - Demonstrou-se experimentalmente que E. herbicola è patogēnica à cana-de-açūcar, atendendo aos postulados de Kock.

f - A P. rubrisubalbicans é passível de causar descoloração vascular em cana-de-açūcar;

g - O tratamento térmico convencional de colmos de cana-de-a çūcar (imersão em àgua quente a $50,5^{\circ} \mathrm{C}$ por duas horas) pa ra controle do RSD, não foi suficiente para inativar totalmente a bactéria $E$. herbicola de material infectado;

h - Existe a possibilidade de que o RSD, atē agora considerada como sendo causada por uma bactéria, seja na verdade causada por um complexo de bactérias;

i - Para se avaliar a importāncia destes organismos estuda dos como parte do complexo de agentes causais do RSD da cana-de-açūcar, os testes de patogenicidade devem ser complementados com experimento de campo que possibilitem averiguar a capacidade de cada organismo isolado provo car danos e reproduzir o quadro sintomatológico completo da enfermidade. 
8 - SUMMARY

Isolations performed from sugar cane stalks showing symptoms of ratoon stunting disease (RSD) yielded bacteria identified as Erwinia herbicola and Pseudomonas rubrisubalbicans. E. herbicola was found in all cultivars tested: IAC $52 / 326, \quad$ Q 28, CP 44-101, CB 41-76, CB 49-260, and IAC $48 / 65$, whereas $P$. rubrisubalbicans was detected in the cultivars IAC 52/326, Q 28 and CP 44-101. Pathogenicity of these bacteria was checked by inoculating plants of cultivar CP 44-101 known to react with early symptoms of internal vascular discoloration supposedly due to infection with the causal agent of RSD.

Evaluations of $E$. herbicola populations present in the juice extracted from the nodal region of sugar cane stalks showing disease symptoms revealed levels in the range of 1.2 to $2.8 \times 10^{8}$ and 0.7 to $3.8 \times 10^{6}$ viable cells per milliliter for the cultivars IAC $48 / 65$ and IAC $52 / 326$, respectively. 
Results indicated that $E$. herbicola must be involved in the etiology of RSD and that $P$. rubrisubalbicans should be investigated further. E. herbicola was found to be constantly associated with diseased tissues, was able to reproduce part of the symptoms when inoculated in sugar cane, and reached relatively high populations in sugar cane stalks.

Isolations performed after heat treatment $\left(50.5^{\circ} \mathrm{C}\right.$ for 2 hours) of sugar cane cuttings from plants with RSD symptoms indicated that this treatment is capable of providing complete inactivation of $P$. rubrisubalbicans, but only partial inactivation of $E$. herbicola.

Hot water treatment of $E$. herbicola and $P$. rubrisubalbicans, "in vitro", revealed that $P$. rubrisubalbicans is completely inactivated when submitted to temperatures of $50^{\circ} \mathrm{C}$ for 20 minutes, whereas for $E$. herbicola, over the same immersion time, temperatures of $54^{\circ} \mathrm{C}$ were required for total inactivation.

Several studies were carried out to investigate the adequacy of using Elephant grass (MATSUOKA, 1972a) as a test plant for RSD diagnosis. Inoculations of the cultivar Merker of this gramineous species were secured with several bacteria, fungi and yeast species. Elephant grass reacted positively and showed vascular discoloration when inoculated with Erwi nia herbicola, E. carotovora, Pseudomonas rubrisubalbicans, P. rubrizineans, P. mori, Xanthomonas albilineans, Fusarium moniziforme, Candida cruzei, Hansenula anomala and 
Saccharomyces cerevisiae. The internal symptoms observed seemed identical to those induced in the test plant inoculated with raw juice extracted from sugar cane stalks with RSD. It was also observed that the degree of reaction depended on the microorganism inoculated and or the number of propagules present in the inoculum. The lowest concentration capable of inducing a positive response was approximately $10^{1}$ propagules per milliliter of suspension, which was achieved with F. moni Ziforme. These data further support that Elephant grass reacts unspecifically through vascular discoloration of nodal regions. Therefore it should not be recommended for RSD diagnostic. 
ASWORTH JR., L. J. ; D. C. HILDEBRANB e M. N. SCHROTH, 1970. Erwinia - induced internal necrosis of immature cotton bolls. Phytopathology, 60: 602-607.

BAILEY, R. D., 1977. The systemic distribution and relative occurrence of bacteria in sugarcane varieties affected by ratoon stunting disease. Proceeedings of the South. Sugar African Technologists' Association. Durban, p. 5556 .

BECHET, G. R., 1976. Ratoon stunting disease and rapid diag nostic techniques. Proceedings of the South African Sugar Technologists' Association. Durban, p. 1-4.

BENDA, G. T. A., 1972. Hot water treatment for mosaic and RSD control. Sugar Journal. N. Orleans, 34(10): 32-39. 
BETTI, J.A. ; A. S. COSTA; 0. PARADELA Fo ; J. SOAVE e S. MATSUOKA, 1976. Descoloração vascular na região dos nōs em capim Elefante causada por vārias espécies de bactérias. Sociedade Brasileira de Fitopatologia. IX Congresso Brasi leiro de Fitopatologia, São Paulo, p. 81 (Resumo).

BOURNE, B. A., 1963. Studies on the heat treatment for the control of ratoon stunting disease of sugarcane in Florida. Proceedings of the $11^{\text {st }}$ Congress of the International Society of Sugarcane Technologists. Mauritius, p. 776-788.

BRADBURY, J.F., 1967. Erwinia herbicola. Commonwealth Mycological Institute. Descriptions of Pathogenic Fungi and Bacteria. no 232.

BUCHANAN, R. E. e N.E. GIBBONS, 1974. Bergey's Manual of Determinative Bacteriology. 8 ed. Baltimore, Williams e Walkins Company, $1.246 \mathrm{p}$.

CARVALHO, P. C.'T., 1963. As viroses da cana-de-açūcar. In: Pragas e Doencas da Cana-de-Açūcar. Piracicaba, ESALQ/USP. Depto. de Fitopatologia e Entomologia, p. 7590 .

CHEN, C. T. ; S. M. LEE e M. J. CHEN, 1975. Small coryne form bacteria in ratoon stunted sugarcane. Sugarcane Pathologists Newsletter. Sydney, $(13 / 14): 6-8$.

CHENULU, V. V., 1960. Ratoon stunting disease of sugarcane. A. review. Indian Journal of Sugarcane Research and Development, $\underline{5}(1): 59-61$

CHO, J. J. ; K. E. ROHRBACH e A. C. HAYWARD, 1978. An Erwinia herbicola strains causing pink disease in pineapple. Proc. IV ${ }^{\text {th }}$ Int. Conf. Plant Pathogenic Bacteria, 2: 433-442. 
CHRISTOPHER, W. N. e C.W. EDGERTON, 1930. Bacterial stripe diseases of sugarcane in Louisina. J.Agric. Res., 4l: $259-267$.

CROSSE, J.E., 1971. Interactions between saprophytic and pathogenic bacteria in plant disease. In: Ecology of leaf-surface organisms. (T. F. PREECE and C. H. DICKIRSON, Eds.), London, Academic Press, p. 283-290.

DAMANN JR., K. E. e K. S. DERRICK, 1976. Bacterium associated with ratoon stunting disease in Louisiana. Sugarcane Pathologists Newsletter. Sidney (15/16): 20-22.

DANTAS, B., 1956. Plano quadrienal para o estudo das princi pais doenças e pragas da cana-de-açūcar em Pernambuco. Pu blicação nọ 2. Comissão de Combate às Pragas de Cana-deAçūcar no Estado de Pernambuco. Recife, 58 p.

DOUDOROFF; M. e N. J. PALLERONE, 1974. Bergey's Manual of Determinative Bacteriology. 8 ed., Baltimore, Maryliand, p. $217-243$.

EIRA, A. P., 1972. Fatores que influem na triagem das varie dades de cana-de-açūcar (Saccharum spp.) ao Fusarium moni Ziforme Sheldon, agente causal do "Pokkah Boeng". Tese Doutor em Ciência. F.C.M.B.B., Botucatu, SP. 66 p. mimeografado.

EL-BANNA, M. T. ; M. A. MOURSI e F. NOUR-EL-DIN, 1967. Studies on sugarcane ratoon stunting virus disease. (A) Properties of the causal virus and control of the disease. The Agricultural Research Review. Cairo, 45: 74-92. 
FORBES, I. L. ; R. J. STEIB e S. J. P. CHILTON, 1960. Ratoon stunting disease of sugarcane. Agricultural Experiment Sta tion. Bulletin 532. Louisiana, $23 \mathrm{p}$.

GALLI, F. ; H. TOKESHI ; P. C. T. CARVALHO ; E. BALMER ; H. KI MATI ; C. O. N. CARDOSO e C. L. SALGADO, 1968. Manual de Fitopatologia: Doenças das plantas e seu controle. São Paulo. Ed. Agronōmica Ceres, $640 \mathrm{p}$.

GALLI, F. ; P. C. T. CARVALHO ; H. TOKESHI ; E. BALMER ; H. KI MATI ; C. O. CARDOSO ; C: L. SALGADO ; T.L. KRUGNER ; E.J. B. N. CARDOSO e A. BERGAMIN Fo, 1980. Manual de Fitopatologia: Doenças das plantas cultivadas. São Paulo. Ed. Agronōmica Ceres, 2a ed., vol. 2, $587 \mathrm{p}$.

GIBBINS, L. N., 1978. Erwinia herbicola: A review and pers pective. Proc. IV ${ }^{\text {th }}$ Int. Conf. Plant Pathogenic Bacteria, 2: $\quad 403-432$.

GILLASPIE JR., A. G., 1970a. Evidence that ratoon stunting disease of sugarcane is caused by virus and not mycoplasma. Phytopathology. Lancaster, 60(10): 1448-1450.

GILLASPIE JR., A. G., 1970b. Ratoon stunting disease: distribution in the sugarcane plant. Sugar Bulletin. Loui siana, $48(16)$ : 200-201.

GILLASPIE JR., A. G., 1971. Ratoon stunting disease virus: problems in purification. American Society of Sugar Cane. Technologists. Baton Rouge, 1: 52-56.

GILLASPIE JR., A. G. ; R. E. DAVIS e J. F. WORLEY, 1973. Diagnosis of ratoon stunting disease based on the presence of a specific microorganism. Plant Disease Report. Washington, 57(12): 987-990. 
GILLASPIE JR., A. G. ; R. E. DAVIS e J. F. WORLEY, 1976. Na ture of the bacterium associeted with ratoon stunting di sease of sugarcane. Sugarcane Pathologists Newsletter. Sydney $(15 / 16): 11-15$.

GILLASPIE JR., A. G. ; R. E. DAVIS e J. F. WORLEY, 1975. Na rute of the ratoon stunting disease agent. Sugar Journal. N. Orleans, $38(4):$ 7-10.

GRAHAM, D. C., 1958. The status of Erwinia Zathyri and related bacteria. Commonwealth Phytopathol - News, 4: 4951.

HALE, C. N. e J. P. WILKIE, 1972. A comparative study of Pseudomonas species pathogenic to sorghum. N. Z. J.Agric. Res., 15: 448-456.

HAYWARD, A. C., 1962. Studies on bacterial pathogens of sugarcane. II. Differentiation, taxonomy, and nomenclature of the bacteria causing red stripe and mottled stripe di seases. Mauritius Sugar Industry Research Institute 0cca. sional Paper. (13): 13-27.

HUGHES, C. G., 1955. Some recent development in the study of ratoon stunting disease. Cane Growers' Quarteley Bulletin. Brisbane, 19(1): 27-28.

HUGHES, C. G., 1956. Disease investigations: Ratoon stunting disease. Annual Report, Queesland Bureau of Sugar Experiment Stations. Brisbane, no 56, p. 81-84.

HUGHES, C. G. e D. R. L. STEINDL, 1955. Ratoon stunting disease of sugarcane. Technical Communication. Queesland. Bureau of Sugar Experiment Stations, Brisbane, no $2,54 \mathrm{p}$. 
IRWINE, J. E., 1976. Factors affecting the expression of juvenile symptoms of the ratoon stunting disease. Proceedings of the American Society of Sugarcane Technologists. Baton Rouge, $\underline{5}$ (NS): 109-113.

LELLIOT, R. A., 1974. In: BUCHANAN, R. E. e N. E. GIBBONS, (Editores). Bergey's Manual of Determination Bacteriology. 8 ed., Baltimore, Maryland, The Williams \& Wilkins Co., Ltd. p. 332-339.

LOPEZ-ROSA, J. A H. ADSUAR, 1970. Effect of stunting disease on yield of some sugarcane varieties in Puerto Rico. Journal of Agriculture of University of Puerto Rico, 54: 149-169.

MAMIUNTEN, H. e S. WAKIMOTO; 1976. Coryneform bacteria found in xylem of the ratoon stunting diseased sugarcane. Annual. Phytopathological Society of Japan, 42: 500-503.

- MATSUOKA, S., 1971. Elefant grass, an indicator for ratoon stunting virus of sugarcane. Plant Protection Bulletin. FAO, Rome, $\underline{9}(5)$ : $110-115$.

MATSUOKA, S., 1972a. Raquitismo da soqueira da cana-de-açūcar: diagnose da moléstia e estudos sobre o seu agente causal. Piracicaba, ESALQ/USP, 77 p. (Tese de Doutoramento).

MATSUOKA, S., 1972b. Ratoon stunting disease diagnosis with elephant-grass as a indicator plant. Sugarcane Patholo. gists Newsletter. Sydney (ㅇ) : 10-11. 
NEDER, R. N., 1957. Contribuição ao estudo de algumas leveduras regionais de fábricas de aguardente de cana - posi ção sistemática e valor industrial. Piracicaba, ESALQ/USP. $79 \mathrm{p}$. (Tese de Doutoramento).

RICAUD, C., 1974. Problems in the diagnosis of ratoon stunting disease. Proceedings of the $15^{\text {th }}$ Congress. International Society of Sugarcane Technologists. Durban, p. 241-249.

RICAUD, C. ; S. SULLIVAN e J. C. AUTREY, 1976. Presence of the RSD associated bacterium in Mauritius. Sugarcane Pathologists Newsletter. Sydney, (17): 37-39.

SANHUEZA, R. M. V., 1979. Relações entre Xanthomonas albili neans, Erwinia herbicola e Pseudomonas sp. em Cana-de-açū car. Piracicaba, ESALQ/USP. 77 p. (Dissertação de Mestrado).

SCHEXNAYDER, C. A., 1956. The effect of stunting disease of sugarcane on yield of cane and sugar in Louisiana, and the use of heat treatment for control. Sugar Bulletin, New orleans, 34(22): $349-355$.

SCHEXNAYDER, C. A., 1960. The use of sugarcane "test plant" as a means of detecting the presence of ratoon stunting disease in sugarcane. Proceedings of the $10^{\text {th }}$ Congress. International Society of Sugarcane Technologists. Honolu lu, p. 1068-1072.

SILVA, W. M., 1976. Termoterapia em gemas isoladas assegura o controle do raquitismo. Boletim Técnico da Copersucar. Piracicaba, 76 p. 
STEIB, R. J. e D. M. TANTERA, 1970. Studies to determine the effect of tetracycline antibiotic on the ratoon stunting disease (RSD) of sugarcane. Sugar Bulletin. N. Orleans, $48(17): 217-219$.

STEIB, R. J. ; 0. M. CIFUentes ; B. COChRAN E M. M. MAYEUX, 1976. Control of RSD of sugarcane by use of aerated steam. Sugar Journal. N. Orleans, 39(2): 20-23.

STEIB, R. J. e S. J. P. CHILTON, 1972. Losses caused by RSD and need for hot air treatment. Sugar Bulletin. N. Orleans, $50(19): 8-11$.

STEINDL, D. R. L., 1976a. New method of identifying ratoon stunting disease. Cane Growers Quarterly Bulletin. Brisbane, $39(4): 130-131$.

STEINDL, D. R. L., 1976b. The use of phase-contrast microscopy in the identification of ratoon stunting disease. Proceedings of Queensland Society of Sugarcane Technolo.gists. 43rd Conference. Brisbane, p. 71-72.

STEINDL; D. R. L. e C. G. HUGHES, 1953. Ratoon stunting disease. Cane Growers' Quarterly Bulletin. Brisbane, 16 (3): $79-95$.

STEINDL, D. R. L. e D. S. TEAKLE, 1974. Recent developments in the identification of ratoon stunting disease. Proceedings of the Queensland Society of Sugarcane Technologists. 4lst Conference, Brisbane, p. 101-104.

SUZUKI, Y. e UCHIDA, K., 1965. Microbiological studies of phytopathogenic bacteria. I. On 2-ketogluconic acid fermentation by the bacteria belonging to the Erwinia amyzovo ra Group. Agric. Biol. Chem. (Tokyo), 29: 462-470. 
TEAKLE, D. S., 1974. The causal agent of sugarcane ratoon stunting disease (RSD). Proceedings of the $15^{\text {th }}$ Congress. International Society of Sugarcana Technologists. Durban, p. 225-233.

TEAKLE, D. S. ; P. M. SMITH e D. R. L. STEINDL, 1973. Association of a small coryneform bacterium with the ratoon stunting disease of sugarcane. Australian Journal of Agri cultural Research. Melbourne, 24: p.869-874.

TODD, E., 1960. The ratoon stunting disease of sugarcane and its control in Florida. U.S. Department of Agriculture. Agricultural Research Service, 34(12): 1-7.

TOKESHI, H. ; A. SANGUINO e F. AKIBA, 1974. Xanthomonas albizineans, provāvel agente causal de raquitismo da soqueira e escaldadura de cana-de-açūcar. Brasil Açucareiro. Rio de Janeiro, 84(6): 28-40.

TUITE, J., 1969. Plant Pathological Methods: fungi and bac teria. Minneapolis, Burgess, $239 \mathrm{p}$.

VALARINI, P. J., 1978. Avaliação da resistência ao raquitís mo da soqueira pelo método da vazão de água em colmos de cana-de-açūcar. Piracicaba, ESALQ/USP, 78 p. (Disserta ção de Mestrado).

VEIGA, F. M., 1956. Notas sobre o raquitismo das socas em campos. Brasil Açucareiro. Rio de Janeiro, 47: 81-83.

YOURG, J. M. ; D. W. DYE ; J. F. BRADBURY ; C. G. PANAGOPOULOS e C. F. ROBBS, 1978. A proposed nomenclature and classification for plant pathogenic bacteria. N.Z. J. Agric. Res., 21: 153-177. 
ZUET, T. Van Der, 1969. Study of "fire blight" cankers and associated bacteria in pear. Phytopathology, 59: 607-613. 
73.

$10-A P E \bar{E} D I C E$ 


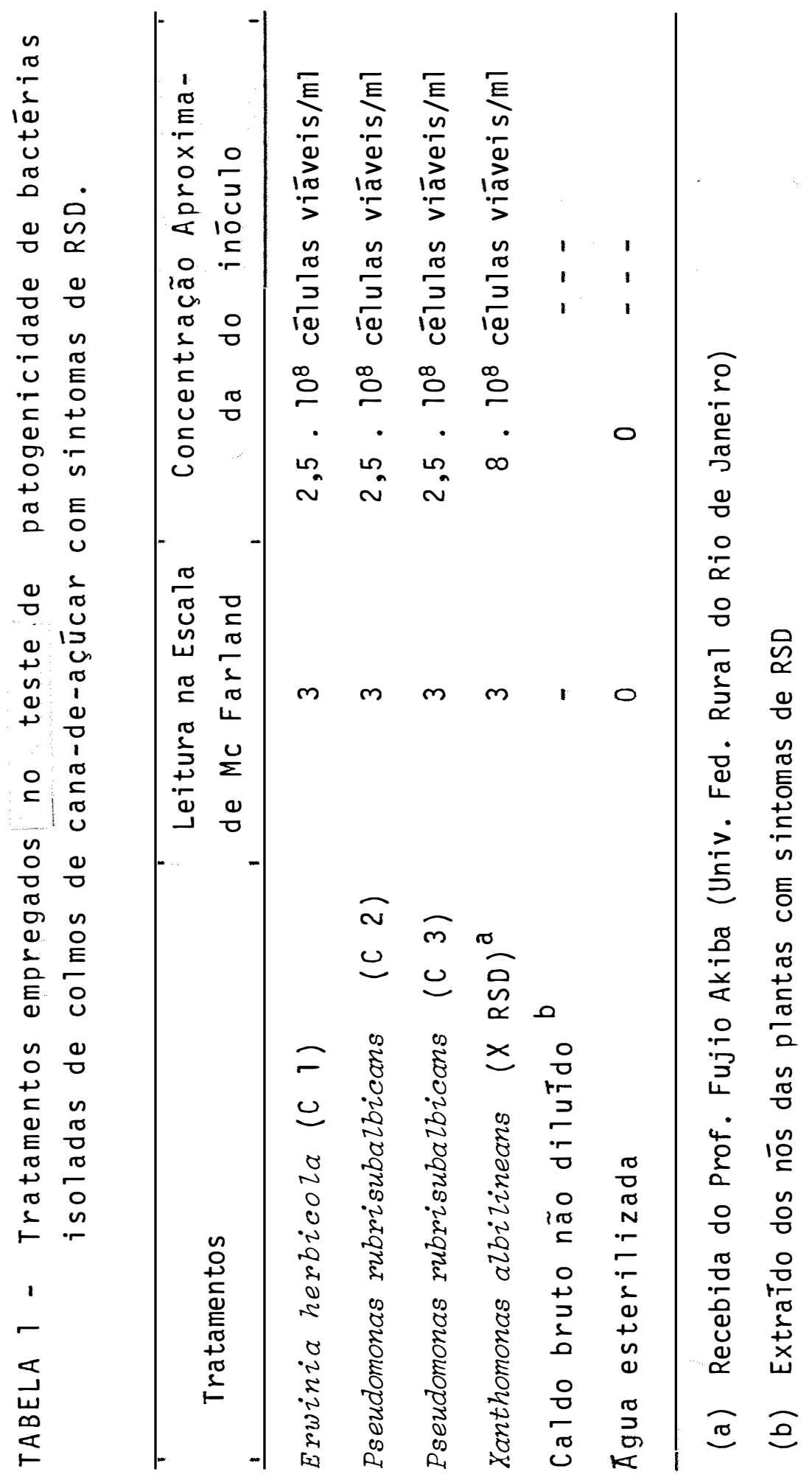




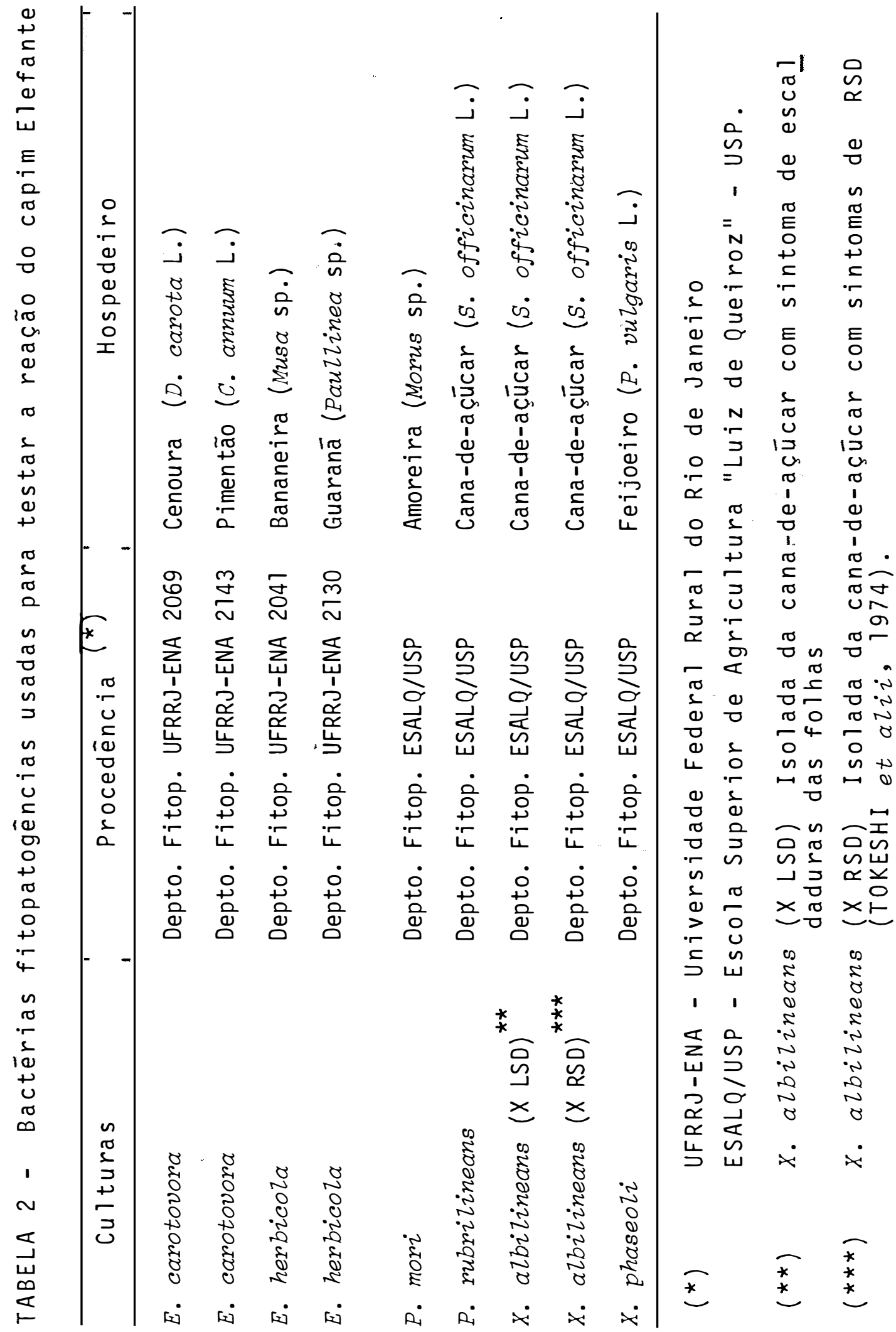


76 .

TABELA 3 - Organismos usados para testar a reação do capim Ele fante à inoculação com bactérias e fungos isolados da cana-de-açūcar, e leveduras encontradas em desti larias de aguardente de cana-de-açūcar

Organismos $\quad$ Procedência $\left({ }^{*}\right)$

Bactērias:
E. herbicola (C 1 )
Depto. Fitop. ESALQ/USP
E. rubrisubarticans (C 2)
Depto. Fitop. ESALQ/USP
E. rubrisubalbicans (C 3)
Depto. Fitop. ESALQ/USP
Xanthomonas albilineans ( $X$ RSD)
Depto. Fitop. ESALQ/USP

Fungos:

Colletotrichom falcation

Fusarizon moniliforme (C 17)

Fusarizon moniliforme (C 24)

Fusarizon moniliforme (C 29)
Depto. Fitop. ESALQ/USP

Depto. Fitop. FCMBB/UNESP

Depto. Fitop. FCMBB/UNESP

Depto. Fitop. FCMBB/UNESP

Leveduras:

Candida cruzei

Inst. Zimot. ESALQ/USP

Candida tropicalis

Inst. Zimot. ESALQ/USP

Hansenula anomala

Inst. Zimot. ESALQ/USP

Saccharomyces carlsbergensis (I.Z. 284 L.)

Inst. Zimot. ESALQ/USP

Saccharomyces cerevisiae (I. Z. 1716)

Inst. Zimot. ESALQ/USP

Schnizosaccharomyces pombae (I.Z. 1354)

Inst. Zimot. ESALQ/USP

(*) ESALQ/USP: Escola Superior de Agricultura "Luiz de Queiroz" - Universidade de São Paulo

FCMBB/UNESP: Faculdade de Ciēncias Médicas e Biológicas de Botucatu - Universidade de São Paulo 
TABELA 4 - Tratamentos empregados para testar a reação do capim Elefante à inocuilação com diferentes concentra ções de: Candida cruzei, Fusarium moniliforme, Hansenula anomala e Saccharomyces cerevisae

\begin{tabular}{lllll}
\hline \multirow{2}{*}{ Tratamentos } & \multicolumn{4}{c}{ Concentrações em talos/ml } \\
\cline { 2 - 5 } & Maxima & Média & Minima \\
\hline C. cruzei & $5 \cdot 10^{6}$ & $5 \cdot 10^{2}$ & $5 \cdot 10^{1}$ \\
F. moniliforme & $5 \cdot 10^{6}$ & $5 \cdot 10^{2}$ & $5 \cdot 10^{1}$ \\
H. anomala & $6.10^{6}$ & $6 \cdot 10^{2}$ & $6.10^{1}$ \\
S. cerevisiae & $7.10^{6}$ & $7.10^{2}$ & $7.10^{1}$ \\
Agua esterilizada & 0 & 0 & 0 \\
\hline
\end{tabular}

TABELA 5 - Tratamentos usados no teste de reação do capim Ele fante à inoculação com diferentes concentrações de bactérias isoladas dos colmos de cana-de-açūcar com sintomas de RSD

Concentrações estimadas em cēlü

Tratamentos las viāveis/ml

\begin{tabular}{lcccc} 
& \multicolumn{1}{c}{ Māxima } & Média & Mínima \\
\hline E. herbicola (C 1) & $2,5 \cdot 10^{8}$ & $2,5 \cdot 10^{4}$ & $2,5 \cdot 10^{3}$ \\
P. rubrisubalbicans (C 2) & $2,5 \cdot 10^{8}$ & $2,5 \cdot 10^{4}$ & $2,5 \cdot 10^{3}$ \\
P. rubrisubalbicans (C 3) & $2,5 \cdot 10^{8}$ & $2,5 \cdot 10^{4}$ & $2,5 \cdot 10^{3}$ \\
X. arbilineans (X RSD) & $8,0 \cdot 10^{8}$ & - & - \\
Agua esterilizada & 0 & 0 & 0 \\
\hline
\end{tabular}


TABELA 6 - Tratamentos empregados para testar a reação do capim Elefante à inoculação com caldo extraído e com bacté rias isoladas de colmos de cana-de-açúcar com sintomas de RSD, submetidos ou não à inativação térmica

Tratamentos

Inativação Térmica a $60^{\circ} \mathrm{C}$ por 25 minutos

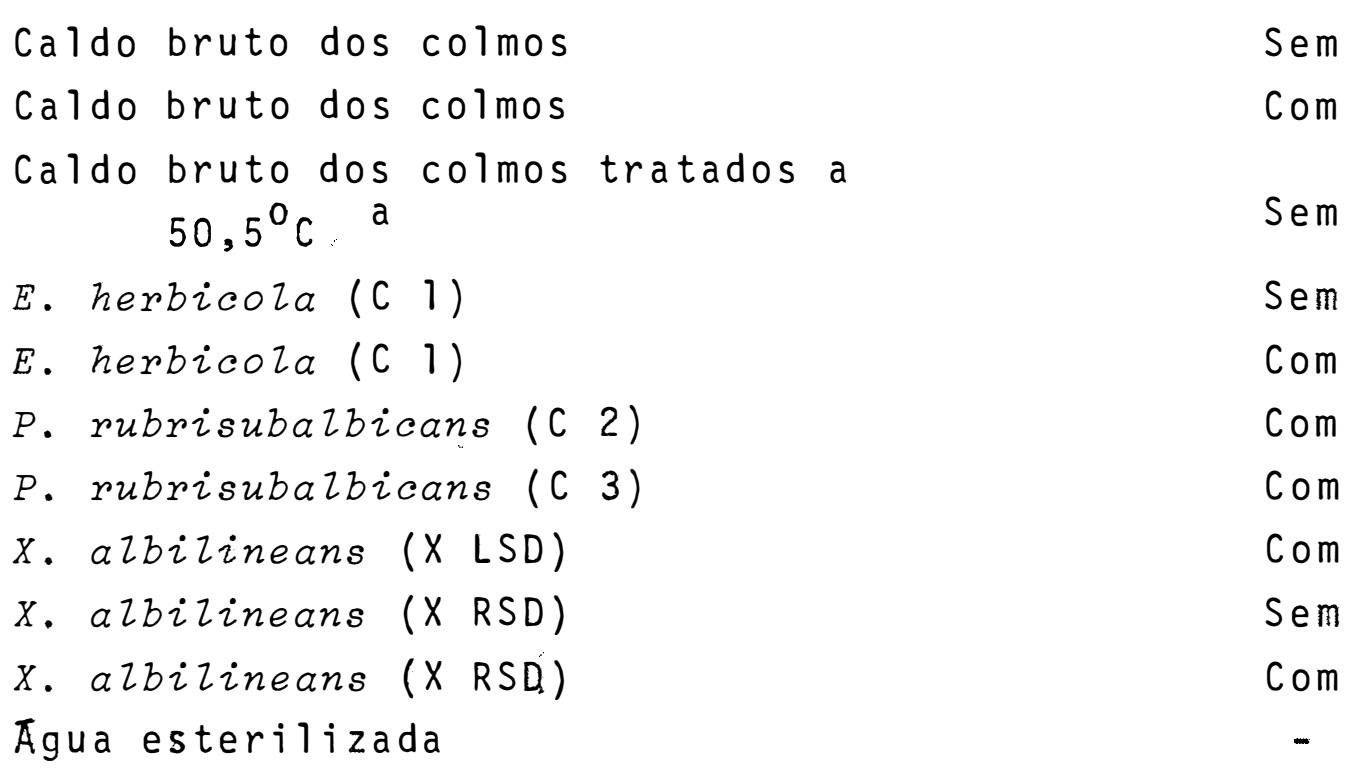

(a) Tempo de tratamento dos colmos $=2$ horas 
TABELA 7 - Teste de patogenicidade das bactérias isoladas de colmos de cana-de-açúcar com sintomas de RSD, em cana-de-açūcar cultivar CB 44-101

\begin{tabular}{lccc}
\hline Tratamentos & $\begin{array}{c}\text { No plantas } \\
\text { inoculadas }\end{array}$ & $\begin{array}{c}\text { No plantas } \\
\text { c/sintomas }\end{array}$ & $\begin{array}{c}\% \text { plantas } \\
\text { c/sintomas }\end{array}$ \\
\hline Caldo bruto & 15 & 15 & 100,0 \\
E. herbicola (C 1) & 15 & 11 & 73,3 \\
P. rubrisubalbicans (C 2) & 15 & 7 & 46,7 \\
P. rubrisubalbicans (C 3) & 15 & 7 & 46,7 \\
X. albilineans (X RSD) & 12 & 3 & 25,0 \\
Agua esterilizada & 15 & 1 & 6,7 \\
\hline
\end{tabular}


TABELA 8 - Populações de E. herbicola (C I) em caldo obtido dos nós de colmos de cana-de-açúcar com sintomas de RSD

\begin{tabular}{|c|c|c|c|}
\hline Cultivares & $\begin{array}{l}\text { Nọ da } \\
\text { planta }\end{array}$ & $\begin{array}{l}\text { Médias do número de colō- } \\
\text { nias nas Placas a }\end{array}$ & $\begin{array}{l}\text { Número de células viāveis } \\
\text { por ml de caldo }\end{array}$ \\
\hline & 1 & 21,1 & $2,11 \cdot 10^{5}$ \\
\hline & 2 & 17,4 & $1,74 \cdot 10^{5}$ \\
\hline \multirow[t]{5}{*}{ IAC $48 / 65$} & 3 & 28,0 & $2,80 \cdot 10^{5}$ \\
\hline & 4 & 22,5 & $2,25 \cdot 10^{5}$ \\
\hline & 5 & eliminado & --- \\
\hline & 6 & eliminado & -- \\
\hline & 7 & 220,3 & $2,20 \cdot 10^{6}$ \\
\hline \multirow[t]{3}{*}{ IAC $52 / 326$} & 8 & 70,1 & $0,70 \cdot 10^{6}$ \\
\hline & 9 & eliminado & --- \\
\hline & 10 & 380,1 & $3,80 \cdot 10^{6}$ \\
\hline
\end{tabular}

(a) Média de cinco placas inoculadas com caldo diluỉdo a $10^{-3}$ 
TABELA 9 - Ponto de inativação térmica "in vitro" das bactérias isoladas de colmos de cana-de-açūcar com sintomas de RSD

\begin{tabular}{|c|c|c|c|c|c|c|}
\hline \multirow{2}{*}{ Bactērias } & \multicolumn{2}{|c|}{ Temperatura } & \multicolumn{4}{|c|}{ tratamento por 20 minutos } \\
\hline & $28^{\circ} \mathrm{C}$ & $48^{\circ} \mathrm{C}$ & $50^{\circ} \mathrm{C}$ & $52^{\circ} \mathrm{C}$ & $54^{\circ} \mathrm{C}$ & $56^{\circ} \mathrm{C}$ \\
\hline 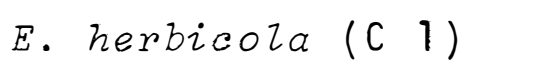 & $(+)$ & $(+)$ & $(+)$ & $(+)$ & $(-)$ & $(-)$ \\
\hline P. rubrisubarbicans ( $C^{2}$ ) & $(+)$ & $(-)$ & $(-)$ & $(-)$ & $(-)$ & $(-)$ \\
\hline P. rubrisubalbicans (C 2) & $(+)$ & $(-)$ & $(-)$ & $(-)$ & $(-)$ & $(-)$ \\
\hline X. albilineans (X LSD) & $(+)$ & $(+)$ & $(-)$ & $(-)$ & $(-)$ & $(-)$ \\
\hline X. albilineans (X RSD) & $(+)$ & $(+)$ & $(+)$ & $(+)$ & $(+)$ & $(-)$ \\
\hline
\end{tabular}

$(+)$ : Presença de cēlulas viāveis apōs o tratamento $(-)$ : Ausència de células viāveis após o tratamento 
TABELA 10 - Descoloração vascular do capim Elefante apōs inoculação com algumas bactērias fitopatogénicas

\begin{tabular}{|c|c|c|c|c|}
\hline \multirow[t]{2}{*}{ Tratamentos } & \multicolumn{3}{|c|}{$\begin{array}{l}\text { Nümero de plantas com } \\
\text { descoloração vascular } \\
\text { em } 20 \text { plantas inocula } \\
\text { das por repetição }\end{array}$} & \multirow[t]{2}{*}{ Médias } \\
\hline & I & II & II I & \\
\hline X. albilineans (X LSD) & 20 & 20 & 20 & $20,00 \mathrm{a}$ \\
\hline$x$, r.bilineans (X RSD) & 20 & 20 & 20 & $20,00 \mathrm{a}$ \\
\hline Nizineans & 17 & 20 & 16 & 17,67 a \\
\hline E. caratovora (ENA 2069) & 9 & 9 & 7 & $8,33 \mathrm{~b}$ \\
\hline P. mori & 8 & 7 & 6 & $7,00 \mathrm{~b}$ \\
\hline E. caratovora (ENA 2129) & 7 & 5 & 6 & $6,00 \mathrm{bc}$ \\
\hline E. caratovora (ENA 2143) & 6 & 6 & 5 & $5,67 \mathrm{bc}$ \\
\hline E. herbicola (ENA 2041) & 3 & 3 & 4 & $3,33 \mathrm{~cd}$ \\
\hline E. herbicola (ENA 2130) & 3 & 2 & 3 & $2,67 \mathrm{~cd}$ \\
\hline X. phaseoli & 1 & 3 & 1 & $1,67 \mathrm{~d}$ \\
\hline Testemunha (água esterilizada) & 1 & 2 & 1 & $1,33 \mathrm{~d}$ \\
\hline C. V. $=10,4 \%$ & $\Delta$ & $=3,3$ & Tuckey & \\
\hline
\end{tabular}

(a): Médias seguidas de letras iguais não diferem estatisticamente 
TABELA 11 - Descoloração vascular do capim Elefante após a ino culação com bactérias e fungos isolados de cana-de - açucar e com leveduras mais comumente encontradas em destilarias de aguardente de cana-de-acúcar

\begin{tabular}{|c|c|c|c|c|c|}
\hline \multirow[t]{2}{*}{ Tratamentos } & \multicolumn{3}{|c|}{$\begin{array}{l}\text { Número de plantas com } \\
\text { descoloração vascular } \\
\text { em } 20 \text { plantas inocula } \\
\text { das por repetição }\end{array}$} & \multirow{2}{*}{\multicolumn{2}{|c|}{ Média }} \\
\hline & I & II & III & & \\
\hline F. monitiforme (C 17) & 12 & 12 & 12 & 12,00 & \\
\hline F. moniliforme (C 24) & 12 & 12 & 12 & 12,00 & \\
\hline F. moniliforme (C 29) & 12 & 12 & 12 & 12,00 & a \\
\hline X. albilineans (X RSD) & 12 & 12 & 12 & 12,00 & a \\
\hline C. cruzei & 8 & 10 & 10 & 9,33 & b \\
\hline E. herbicola (C 1) & 10 & 8 & 10 & 9,33 & b \\
\hline P. rubrisubalbicans ( ( 2 2) & 10 & 8 & 10 & 9,33 & \\
\hline P. rubrisubalbicans ( $\begin{array}{l}C \\
\text { ( 3) }\end{array}$ & 9 & 9 & 10 & 9,33 & b \\
\hline H. anomala & 5 & 7 & 7 & 6,33 & c \\
\hline S. cerevisiae & 5 & 6 & 6 & 5,67 & c \\
\hline S. carlsbergensis & 2 & 1 & 2 & 1,67 & d \\
\hline S. pombae & 1 & 1 & 2 & 3,33 & d \\
\hline C. tropicalis & 0 & 1 & 2 & 1,00 & $d$ \\
\hline C. falcatum & 0 & 0 & 1 & 0,33 & $d$ \\
\hline Testemunha (água esterilizada) & 0 & 0 & 1 & 0,33 & d \\
\hline C. $V .=9,6 \%$ & $\Delta$ & $=2$, & (Tucke & & \\
\hline
\end{tabular}

(a): Médias seguidas de letras iguais não diferem estatisticamente 


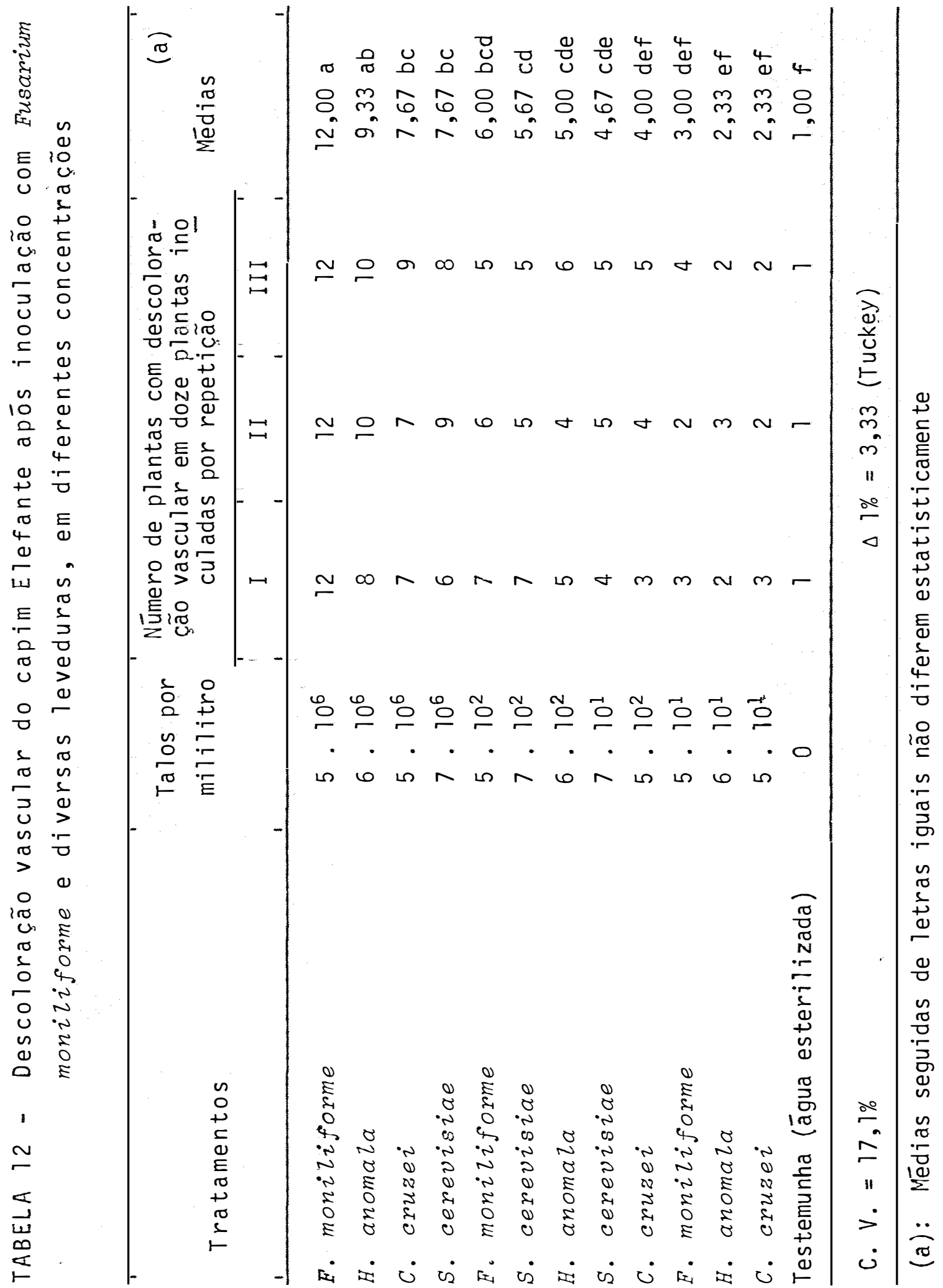


85.

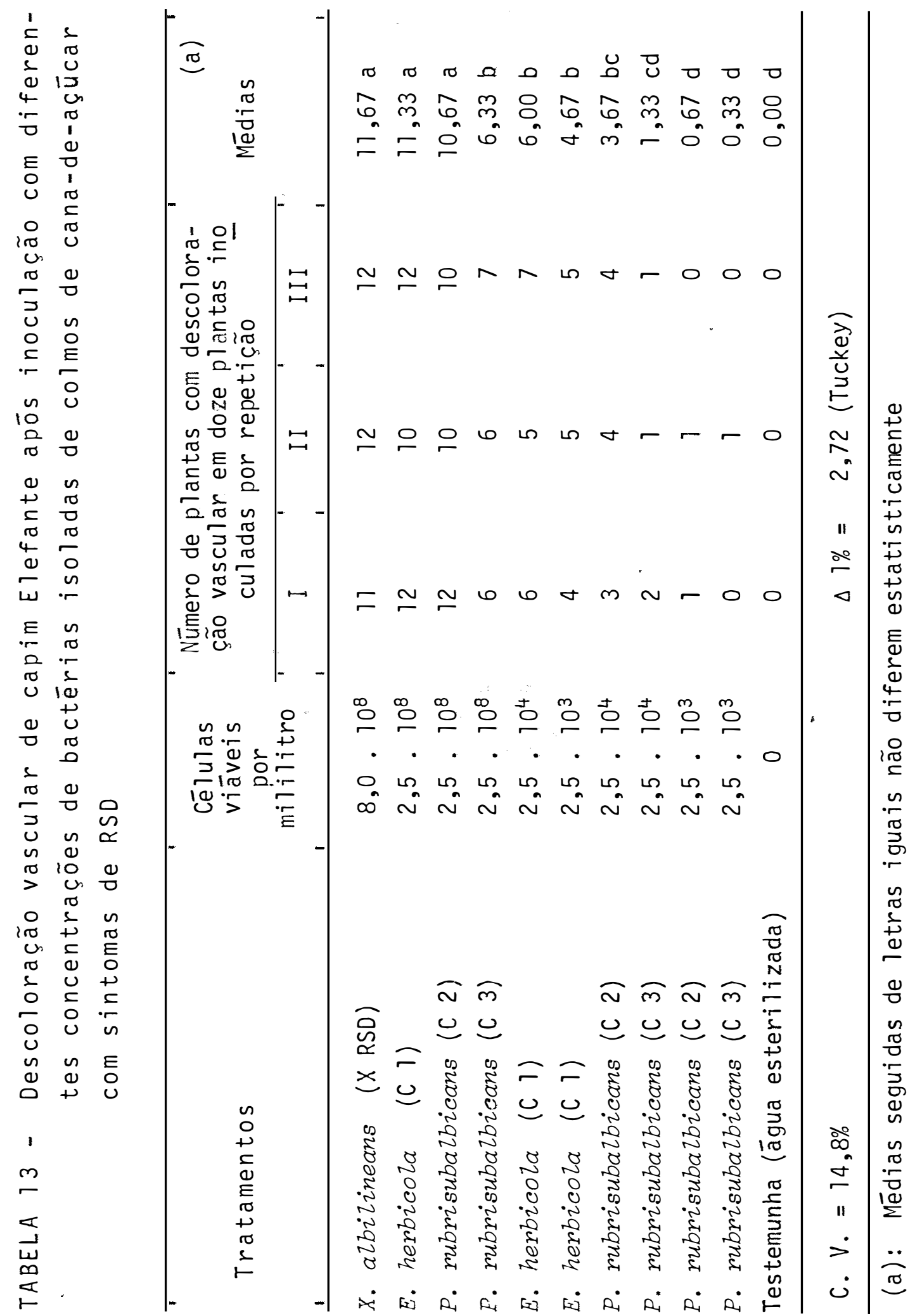




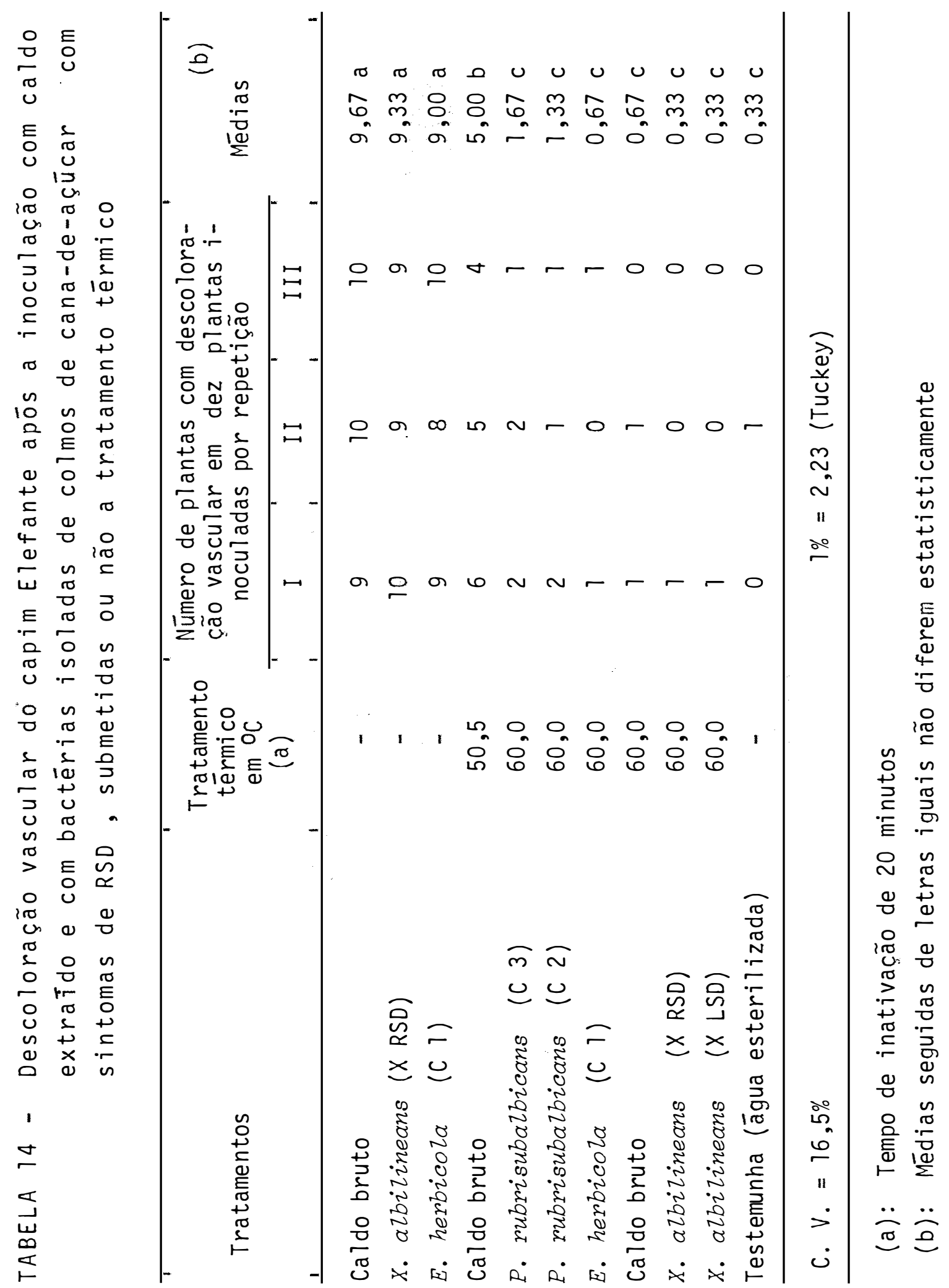

